\title{
Enablers of Six Sigma: contextual framework and its empirical validation
}

\author{
Dubey, $\mathrm{R}$
}

http://hdl.handle.net/10026.1/5542

10.1080/14783363.2015.1075877

Total Quality Management \& Business Excellence

Informa UK Limited

All content in PEARL is protected by copyright law. Author manuscripts are made available in accordance with publisher policies. Please cite only the published version using the details provided on the item record or document. In the absence of an open licence (e.g. Creative Commons), permissions for further reuse of content should be sought from the publisher or author. 


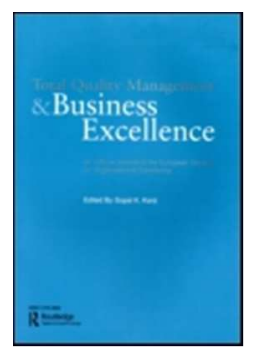

\section{Enablers of Six Sigma: Contextual Framework and its Empirical Validation}

\begin{tabular}{|c|c|}
\hline Journal: & Total Quality Management \& Business Excellence \\
\hline Manuscript ID: & CTQM-2015-0161.R1 \\
\hline Manuscript Type: & Original Article \\
\hline Keywords: & $\begin{array}{l}\text { Six Sigma, Implementation, Interpretive Structural Modelling, MICMAC, } \\
\text { Confirmatory Factor Analysis, Theory Building }\end{array}$ \\
\hline Abstract: & $\begin{array}{l}\text { The aim of the paper is to identify the enablers for the successful } \\
\text { implementation of Six Sigma. None of the existing frameworks provides } \\
\text { any clear understanding related to linkages between, and hierarchical } \\
\text { relationships among, the constructs of Six Sigma implementation. Our } \\
\text { study has both inductive and deductive elements. We identified enablers of } \\
\text { Six Sigma implementation from existing research, and we developed a } \\
\text { contextual framework using the interpretive structural modelling (ISM) } \\
\text { technique. We further studied enablers based on their driving power and } \\
\text { dependence using MICMAC analysis to categorize them enablers into four } \\
\text { clusters. In order to validate the ISM model statistically we developed and } \\
\text { pre-tested a structured questionnaire before using it for a survey. Data } \\
\text { was collected using a split survey method using a modified version of } \\
\text { Dillman's total design method. We performed non-response bias before } \\
\text { checking assumptions such as constant variance and normality. We further } \\
\text { checked the reliability and construct validity using confirmatory factor } \\
\text { analysis. We find that constructs and indicators of our theoretical } \\
\text { framework meet the criteria, and find them to be a good fit based on } \\
\text { confirmatory factor analysis. We draw conclusions based on statistical } \\
\text { analyses and our study limitations, and suggest further research directions. }\end{array}$ \\
\hline
\end{tabular}

\section{SCHOLARONE ${ }^{\text {IT }}$ \\ Manuscripts}




\section{$\underline{\text { Responses to reviewers }}$}

\section{CTQM-2015-0161 Enablers of Six Sigma: Contextual Framework and its Empirical Validation}

\section{Dear Sirs,}

We thank you for your kind comments, which have helped us to improve our paper. Here is a description of the changes we have made.

\section{Reviewer: 1}

Comments to the Author

- Interesting topic and interesting paper on six sigma enablers. Introduction section introduces the research objectives and justification for the study.

Thank you for your kind comments.

- Literature review includes several references related to six sigma. However, connection TQM-BE journal is not very strong and more references to papers in this journal should be added.

Thank you. We have added several papers that have appeared in TQMBE (Burch et al 2014, Cronemyr et al 2014, Jones et al 2010, Kaushik \& Khanduja 2009, Lee \& Choi 2006, Pal Pandi et al 2014, Prashar 2015, Tanik \& Sen 2012)

- Cluster figure 3 is interesting and should be described in detail.

Thank you. We have added some text to explain the axes. We have also changed the figure to show the codes for the enablers instead of their co-ordinates. This should make the diagram easy to understand.

- Methodology section - the work has been done as a part of research project, further details of the project background might be useful for the reader.

Thank you. We realise that the mention of the wider study will raise questions for some readers. But to preserve focus we cannot open up matters that will be the subject of other papers. It may perhaps be simpler to leave out this comment but it does explain why the survey might have been off-putting.

- Conclusion section reads well and further research section makes sense.

Thank you.

Overall, an interesting paper which is in the journal domain; some polishing needed.

Thank you, we have also revised the grammar, expression and punctuation throughout. 


\section{Reviewer: 2}

\section{Comments to the Author}

In some parts of the paper, mainly when presenting statistical results, the paper could be shortened, because there is no need for explaining the definition of all the statistical indicators provided, most of them are well known

Thank you, we believe that a few brief words on the statistics should be helpful for the reader, but we have reduced this. 


\title{
Enablers of Six Sigma: Contextual Framework and its Empirical Validation
}

\begin{abstract}
The aim of the paper is to identify the enablers for the successful implementation of Six Sigma. None of the existing frameworks provides any clear understanding related to linkages between, and hierarchical relationships among, the constructs of Six Sigma implementation. Our study has both inductive and deductive elements. We identified enablers of Six Sigma implementation from existing research, and we developed a contextual framework using the interpretive structural modelling (ISM) technique. We further studied enablers based on their driving power and dependence using MICMAC analysis to categorize them enablers into four clusters. In order to validate the ISM model statistically we developed and pre-tested a structured questionnaire before using it for a survey. Data was collected using a split survey method using a modified version of Dillman's total design method. We performed non-response bias before checking assumptions such as constant variance and normality. We further checked the reliability and construct validity using confirmatory factor analysis. We find that constructs and indicators of our theoretical framework meet the criteria, and find them to be a good fit based on confirmatory factor analysis. We draw conclusions based on statistical analyses and our study limitations, and suggest further research directions.
\end{abstract}

Keywords: Six Sigma, Implementation, Interpretive Structural Modelling, MICMAC, Confirmatory Factor Analysis, Theory Building

\section{Introduction}

Six Sigma has been embraced as a guide to improving organizational productivity (e.g. Kumar et al, 2008). Braunscheidel et al. (2011) argued that Six Sigma is one of the innovations which has taken the quality revolution to 
the next level like total quality management (TQM). While the Six Sigma approach has been increasingly examined by academia and practitioners as a business performance enhancing philosophy (Lee and Choi, 2006; Choi et al. 2012), it has gained little popularity with the operations management community. In addition the Six Sigma literature has failed to generate comprehensive theories and embrace mixed research design which would take the current Six Sigma research forward (e.g. Schroeder et al., 2008; Zu et al., 2008).

A possible reason for this situation is probably the youth of the field. For example, Swamidass (1991) has argued that in comparison to other organizational sciences the operations management field is too young to embrace empirical research. Since 1991, operations management has witnessed a significant rise in empirical research based papers. However, at the same time, within the operations management community one section has constructively argued for the need for alternative methods to advance operations management research. In the past most of the research in POM (Production \& Operations Management) used normative methods which primarily evolved from management science or operations research. Ketokivi and Choi (2014) have argued that in recent years there has been an exponential rise in the use of case research methodology to generate theories. Voss et al. (2002) have argued that case research is a powerful method as far as theory building is concerned. However at the same time Ketokivi and Choi (2014) felt that most of the case research methodology had failed to generate comprehensive theories. Meredith (1998) argued that case research can be used as an alternative theory building tool; however the case research method has several shortcomings. Case study research requires direct observations of cost, time and other related information. Nair et al. (2011) used the action research method as an alternative method to generate theory. However Aldag and Stearns (1988) have further argued that qualitative research methods lack the reliability and validity of constructs needed for building theory. Hence we argue that there is need for mixed research which uses a qualitative approach to generate good theory; and to further test the theory a quantitative method can be used. In this paper, our attention is focussed on the implementation of 
Six Sigma in practice, based upon literature and upon experiences gained in manufacturing in India.

Hence we have derived three research objectives for our present paper:

(1) To identify enablers of Six Sigma implementation;

(2) To generate a comprehensive theoretical framework;

(3) To empirically validate the theoretical framework.

In the following sections we discuss the literature related to the research. Section 3 is devoted to the theoretical framework and the formulation of research hypotheses. Section 4 looks into research design. In Section 5 we describe and discuss the statistical analyses. Section 6 will discuss our findings with respect to previous work, present our unique contributions, review the limitations to the work and identify future research directions.

\section{Related literature}

We have adopted systematic literature review as proposed by Tranfield et al. (2003), in preference to a traditional literature review to understand research contributions in field of Six Sigma and to identify research gaps. Our literature work is based on the principle of exclusion and inclusion of literature available from electronic databases including ProQuest, EBSCO, Science Direct, Emerald, Springer, Scopus and Google Scholar and further to include important literature to improve the comprehensiveness of literature review. We have divided our literature review into two broad categories. In one category we have identified reputable journals listed in web of science and Scopus. In the second we focussed on journals which are relevant but not listed by the main reputable indexing bodies, reports and unpublished research (grey literature).

We searched the databases identified using key words Six Sigma, enablers of Six Sigma, Interpretive Structural Modelling (ISM) and Quality Management. We initially identified 156 articles. After applying the exclusion and inclusion principle, we limited our discussions to relevant articles that guided us to develop theory and significant literature that helped us to carry out our survey 
and analyses; consequently we derived our theoretical model. The systematic review is presented in the form of a flowchart in Figure 1.

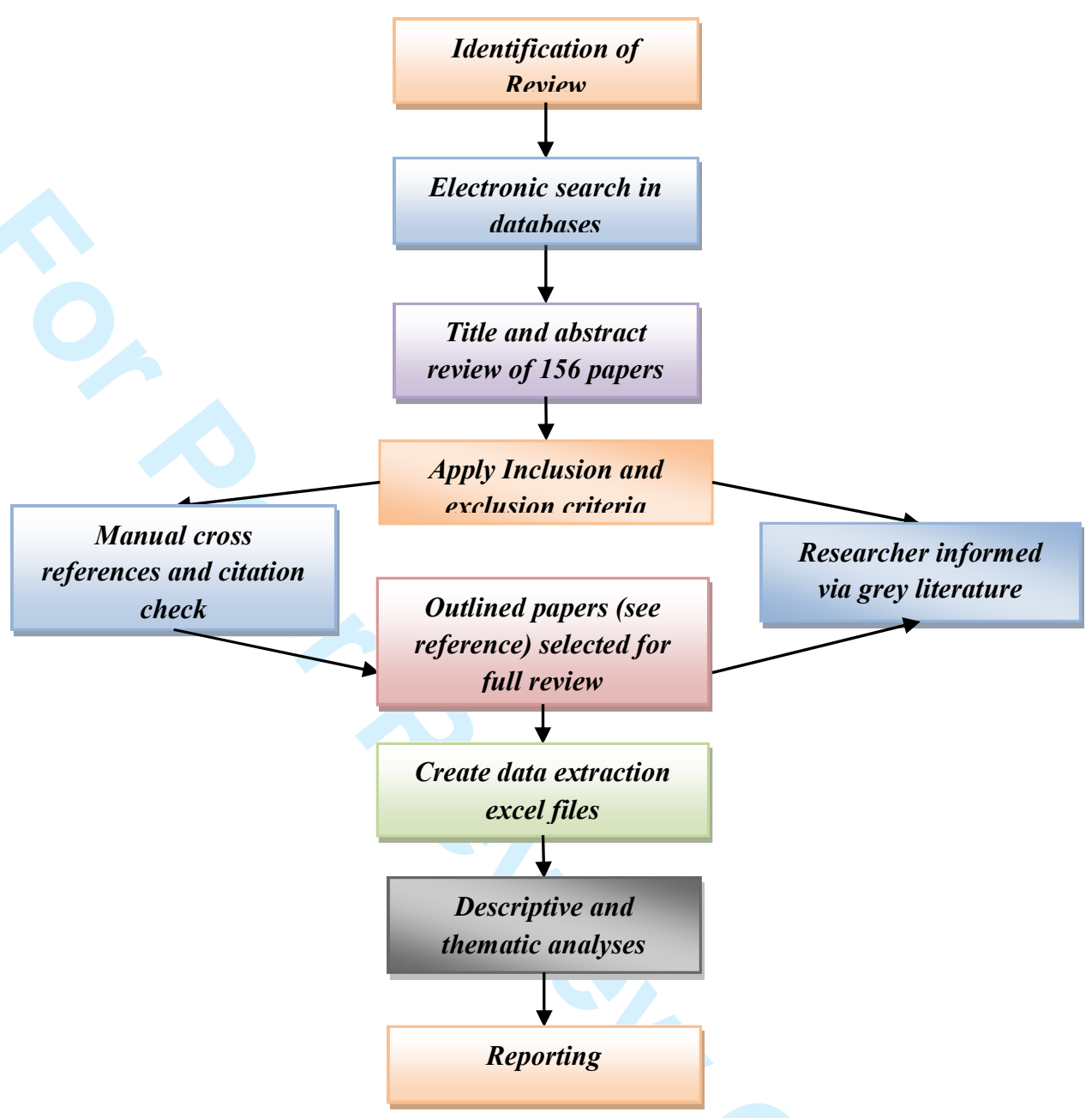

Figure 1: Systematic Review Procedure

We present our systematic literature review in the four following subsections.

\subsection{Emergence of Six Sigma}

Over the years since its inception at Motorola, experts have defined Six Sigma in different ways. Sigma is a statistical measure of the consistency of quality for a particular process or product. Harry (1998) argued Six Sigma as a strategic initiative which helped the organizations to gain in quality which in 
turn boosts profitability, increases market share and improves customer satisfaction through the use of statistical tools (Tiwari et al. 2008; Chakravorty, 2009a; Chakravorty, 2009b; Shafer and Moeller, 2012).

Tomkins (1997) argued that Six Sigma is a tool aimed at elimination of defects from every process, product and transaction. Six-Sigma measures current performance and determines the sigma level from the current average until customer dissatisfaction occurs. A defect is seen as nothing but a reason for customer dissatisfaction (Eckes, 2001; Saghei, 2012). Breyfogle et al. (2001) argued that Six Sigma has evolved over the years as a blend of organizational wisdom with statistical tools to improve upon the effectiveness and efficiency with which the organization can meet customer demands. Shafer and Moeller (2012) have further argued that Six Sigma as a tool offers competitive advantage to the organizations. Jin et al. (2011) argued that Six Sigma is undoubtedly a strategic business initiative rather than simply a quality improvement. Six Sigma has made the journey from one of the quality improvement processes (Linderman et al. 2003) to a powerful business philosophy (e.g. Schroeder et al. 2008; Zu et al. 2008; Pepper and Spedding, 2010). However the research undertaken in context to Six Sigma has failed to generate powerful theories. Except for some notable contributions, most of the literature in Six Sigma lacks theory and most of the studies have failed to develop an integrated theory which can help to explain the success or failure of Six Sigma programs within organizational space. Hence we argue that although Six Sigma evolved as powerful business philosophy the theory surrounding Six Sigma is still underdeveloped.

\subsection{What are the alternative research methods?}

In recent years theory building in operations management has attracted serious attention (e.g. Flynn et al. 2000; Meredith 1998; Handfield and Melnyk 1998; Wacker 1998 and 2004; Bertrand and Fransoo 2002; Linderman et al. 2003; Chen and Paulraj 2004; Schroeder et al. 2008; Zu et al. 2008; Ketokivi and Choi 2014; Markman and Krause 2014). Since the seminal article by Eisenhardt (1989) there has been a significant rise in case based research. 
However, we have argued in preceding discussions that Six Sigma has attracted relatively little attention from operations management community from a theory building point of view; however there are notable contributions which have helped to take the Six Sigma research from methodological perspective to next level (e.g. Schroeder et al. 2008; Zu et al. 2008; Nonthaleerak and Hendry 2008; Zu et al. 2010; Anand et al. 2010; Nair et al. 2011; deMast and Lokkerbol 2012; Easton and Rosenzweig 2012; Arumugam et al. 2013). However most of these notable contributions (except Schroeder et al. (2008), Nonthaleerak and Hendry (2008) and Nair et al. (2011)) are empirical in nature, using literature review to generate theory or literature review with exploratory research using a structured questionnaire. Markman and Krause (2014) argued that empirical research using the deductive approach tends to limit the scope of the research. Hence we argue, based on the cited literature, that the use of an alternative research method in Six Sigma has immense potential to generate theory which is currently scant in the literature.

Alternative methods that have been employed in related areas include case research methods (e.g. Nonthaleerak and Hendry, 2008; Kaushik and Khanduja,2009; Sinha and Firka, 2010; Gijo and Scaria, 2014; Burch et al. 2014; Prashar, 2015), action research methods (e.g. Banuelas and Antony, 2002; Nair et al. 20110, grounded theory (e.g. Schroeder et al. 2008; Chakrabarty and Kay Chuan, 2009; Krueger et al. 2014), and ethnographic studies (e.g. McAdam and Lafferty, 2004). Hence we can argue that beside case research there are other popular alternative methods such as action research, grounded theory and ethnographic studies which have not been exploited by the operations management community for generating good Six Sigma theories.

\subsection{Identification of enablers of Six Sigma}

To identify enablers of Six Sigma, we have undertaken an extensive literature review. There are various studies conducted by scholars in the past where they have attempted to address the enablers or critical success factors of Six Sigma implementation. Before we discuss enablers, we would like to resolve the current debate related to enablers and critical success factors (CSFs). Soti et al. (2010) argued in their study that enablers are those factors that help in the 
successful implementation of Six Sigma. However, in management literature the term 'critical success factors' (CSFs) has been used increasingly since it was popularized by Rockart in 1979. The CSFs were originally those enablers which are critically important to the success of the organisation in a strategic sense. However in our present study we would like to use the term 'enablers' as our objective is to generate theory using these enablers.

Antony et al. (2005) argued that top management involvement and participation, linking Six Sigma to customers, and linking Six Sigma to the business strategy of the organization are the most important factors of Six Sigma implementation. Jones et al. (2010) argued that executive commitment and the role of Black Belts are significant in the implementation of Six Sigma. Soti et al. (2010) argued that top management role, quality maturity level of the organization, availability of funds, organizational infrastructure, availability of expertise training, statistical thinking, employees' adaptability and flexibility towards learning, committed workforce, a reliable data gathering and retrieval system, technical competence and organizational culture have played a significant role in the successful implementation of Six Sigma in an organization. Krueger et al. (2014) have argued that executive commitment, Six Sigma champions, and training play a significant role in the successful implementation of Six Sigma. Zhang et al. (2014) identified seven factors that have played significant roles in the successful implementation of Six Sigma: top management involvement, career plan for best employees, Six Sigma infrastructure, well-established action-learning training systems, information system, Sig Sigma culture, and integration with other management methods. Monteiro et al. (2014) identified three critical success factors (CSFs) for successful implementation of Six Sigma program in Brazilian companies: organisation, infrastructure, and human resources.

Hence we argue that there is a need for study that will help the organizations to identify the key enablers for successful implementation of Six Sigma and further to understand the relationships amongst the key enablers. We have outlined some key enablers as shown in Table 1. 
Table 1: Enablers of Six Sigma

\begin{tabular}{|c|c|}
\hline Enablers & References \\
\hline $\begin{array}{l}\text { Top management } \\
\text { commitment }\end{array}$ & $\begin{array}{l}\text { Coronado and Antony (2002); Antony et al. (2005); } \\
\text { Antony (2006); Kwak and Anbari (2006); Zu et al. } \\
\text { (2008); Aboelmaged (2010); Jones et al.(2010); Soti et } \\
\text { al. (2010); Tanik and Sen (2012); Krueger et al. (2014); } \\
\text { Zhang et al. (2014). }\end{array}$ \\
\hline $\begin{array}{l}\text { Understanding of Six } \\
\text { Sigma methodology }\end{array}$ & $\begin{array}{l}\text { Antony and Banuelas (2002) ; Kwak and Anbari (2006); } \\
\text { Antony (2006); Gosnik \& Vujica (2010); Desai et al. } \\
\text { (2011) }\end{array}$ \\
\hline $\begin{array}{l}\text { Linking Six Sigma to } \\
\text { suppliers }\end{array}$ & $\begin{array}{l}\text { Antony and Banuelas (2002); Antony et al. (2005); } \\
\text { Kwak and Anbari (2006); Antony (2006); Antony and } \\
\text { Desai (2009); Gosnik and Vujica, (2010) }\end{array}$ \\
\hline $\begin{array}{l}\text { Linking Six Sigma to } \\
\text { customers }\end{array}$ & $\begin{array}{l}\text { Antony and Banuelas (2002); Antony et al. (2005); } \\
\text { Kwak and Anbari (2006); Antony (2006); Antony and } \\
\text { Desai (2009); Gosnik and Vujica, (2010) }\end{array}$ \\
\hline $\begin{array}{l}\text { Project management } \\
\text { skills }\end{array}$ & $\begin{array}{l}\text { Antony and Banuelas (2002); Kwak and Anbari (2006); } \\
\text { Antony (2006);Gosnik and Vujica (2010); Nair et al. } \\
\text { (2011) }\end{array}$ \\
\hline Organizational culture & $\begin{array}{l}\text { Antony and Banuelas (2002); Kwak and Anbari (2006); } \\
\text { Antony and Desai (2009); Gosnik and Vujica, (2010); } \\
\text { Zu et al. (2010); Tanik and Sen (2012);Cronemyr et al. } \\
\text { (2014) }\end{array}$ \\
\hline Training & $\begin{array}{l}\text { Antony and Banuelas (2002); Kwak and Anbari (2006); } \\
\text { Antony et al. (2005); Antony (2006); Soti et al. (2010); } \\
\text { Easton and Rosenzweig (2012); Tanik and Sen (2012); } \\
\text { Krueger et al. (2014); Zhang et al. (2014); Monteiro de } \\
\text { Carvalho et al. (2014) }\end{array}$ \\
\hline $\begin{array}{l}\text { Linking Six Sigma to } \\
\text { employees }\end{array}$ & $\begin{array}{l}\text { Kwak and Anbari (2006); Antony (2006); Gosnik and } \\
\text { Vujica (2010); Zhang et al. (2014) }\end{array}$ \\
\hline Communication plan & $\begin{array}{l}\text { Coronado and Antony (2002); Antony and Banuelas } \\
\text { (2002); Kwak and Anbari (2006); Zu et al. (2008); } \\
\text { Linderman et al. (2006); Swink and Jacobs (2012) }\end{array}$ \\
\hline Statistical thinking & $\begin{array}{l}\text { Schroeder et al. (2008) ; Kumar et al. (2008); Soti et al. } \\
(2010)\end{array}$ \\
\hline $\begin{array}{l}\text { Organizational } \\
\text { structure }\end{array}$ & $\begin{array}{l}\text { Antony and Desai (2009); Desai et al. (2011); Monteiro } \\
\text { de Carvalho et al. (2014) }\end{array}$ \\
\hline $\begin{array}{l}\text { Linking Six Sigma to } \\
\text { business strategy }\end{array}$ & $\begin{array}{l}\text { Kwak and Anbari (2006); Antony (2006); Desai et al. } \\
\text { (2011); Gosnik andVujica (2010); Shafer and Moeller }\end{array}$ \\
\hline
\end{tabular}




\begin{tabular}{|l|l|}
\hline & (2012) \\
\hline $\begin{array}{l}\text { Project prioritisation } \\
\text { and selection }\end{array}$ & $\begin{array}{l}\text { Kwak and Anbari (2006); Gosnik andVujica (2010); Nair } \\
\text { et al. (2011) }\end{array}$ \\
\hline Availability of funds & $\begin{array}{l}\text { Kwak and Anbari (2006); Soti et al. (2010); Heckl et } \\
\text { al.(2010) }\end{array}$ \\
\hline $\begin{array}{l}\text { Qualitative data } \\
\text { processing }\end{array}$ & Chakravorty (2009); Kim (2010); Nair et al. (2011) \\
\hline Black Belt & $\begin{array}{l}\text { Kwak and Anbari (2006); Chakravorty (2009); Jones et } \\
\text { al. (2010); Krueger et al. (2014) }\end{array}$ \\
\hline $\begin{array}{l}\text { Career best plan for } \\
\text { employees }\end{array}$ & $\begin{array}{l}\text { Buch and Tolentino (2006); Heckl et al. (2010);Zhang et } \\
\text { al. (2014) }\end{array}$ \\
\hline
\end{tabular}

\subsection{Research Gaps}

We have attempted to build our discussions on the literature that has aimed to generate theories. We have analyzed the current literature using a theoretical lens that considers operations management theories according to three levels as argued in the seminal article by Swamidass (1990). In Level 1 Swamidass (1990) argued that there are general/ unified theories/ grand theories. Level 2 focuses on mid-range theories and Level 3 ideas are termed as empirical generalizations. The literature makes a limited contribution to empirical generalizations and most of the current literature has failed to connect the empirical generalization with mid-range theories. Hence we find immense scope in the Six Sigma field from theory building point of view; this is one of the most neglected areas.

\section{Theoretical Framework}

The theoretical framework is the core of any empirical research. We have critically reviewed some of the Six Sigma implementation frameworks including Linderman et al, 2003; Antony et al, 2005; Linderman et al, 2006; Schroeder et al, 2008; de Treville et al, 2008; Jones et al, 2010; Jeyraman and Teo, 2010; Brun, 2011; Arumugam et al, 2013. 
Before we develop our theoretical framework we must answer some fundamental questions (Sushil, 2012; Whetten, 1989). The three fundamental questions are what, how and why as outlined in a seminal work "What constitutes a theoretical contribution?" (Whetten, 1989). The key questions what, how and why form the basis of our paper. Any theory is supposed to define the basic constructs, dimensions or elements constituting the framework (what). The next question that needs to be delineated in the conceptualization phase is the hypothesized relationships among the research variables (how). Further, the causal thinking (why) must be deliberated in order to explain the linkages among constructs that are envisaged as hypotheses.

The questions in the preceding discussions in theory building may either be obtained from literature using theories or models already validated by other researchers, or may be explored using grounded theory (Strauss and Corbin, 1990) in areas where adequate conclusive literature is not available. Grounded theory seeks inputs from the field in terms of qualitative views from working professionals or experts based on their experience in the problem domain under investigation or by using case experiences in an inductive manner (Sushil, 2012; Strauss and Corbin, 1990). Organizational researchers may find it easy to answer "what" either from literature or field or both so as to identify key variables as the starting point in any research query. They may use past theories to back "how" and "why". However, in grounded theory applications, although the explicit procedure of content analysis methodology is provided to identify the variables or elements, the methodological framework is comparatively weak to answer "how" and "why" in terms of relationships. Such inter-linkages of research elements are portrayed by organizational researchers using some possible logic as they seem to be working on a case to case basis. The grounded theory in such contexts fails to answer "how". However, in such a situation, systems theory and systems engineering may provide enough support to organizational researchers on this front (Sushil, 2012). Structural models may include interaction matrices and graphs (Warfield, 1974).

We have reviewed some of the Six Sigma frameworks and their enablers as outlined in Table 1 in section 2.3. However, none of these frameworks provides 
any clear understanding related to linkages between, and hierarchical relationships among, these constructs. Second, the proposed model is not empirically tested. In order to resolve these limitations, we will use ISM modelling to develop a theoretical framework where we will consult experts and try to explore possible linkages between the constructs using a matrix known as SSIM (Structural Self Interaction Matrix). However, experts (e.g. Mandal and Deshmukh, 1994; Ali and Govindan, 2011; Sushil, 2012; Pal Pandi et al. 2014) feel that the ISM model has limitations. First, it involves a small sample size which may not be enough for statistical validation; and second, the bias of the managers may creep into the final ISM model. To take care of these two limitations, we have further tested the ISM model using data collected through a survey, and validated each construct of the model using confirmatory factor analyses (CFA).

\subsection{Identification of enablers}

The enablers for successful implementation of Six Sigma were derived from an extensive literature review as discussed in preceding sections. The next step was to use experts to screen the enablers. In order to identify suitable experts we approached various candidates who have very good exposure of Six Sigma implementation. Most of them were certified Black Belts with over 10 years' experience in Six Sigma implementation in their organizations or as consultants. We finally settled on 10 experts from various backgrounds.

To identify the enablers, the available literature about Six Sigma enablers was discussed with the experts. The approach we used was an exploratory method in which several brainstorming sessions were held to screen a final list of 15 enablers out of the listed factors from Table 1 . The fifteen enablers were as shown in Table 2.

Table 2: Filtered list of Enablers of Six Sigma

\begin{tabular}{|c|l|c|}
\hline Symbol & Enabler & Short name \\
\hline V1 & Top management commitment & TMC \\
\hline V2 & Understanding of Six Sigma methodology & FT \\
\hline V3 & Linking Six Sigma to suppliers & S \\
\hline V4 & Linking Six Sigma to customers & C \\
\hline
\end{tabular}




\begin{tabular}{|c|l|c|}
\hline V5 & Project management skills & PM \\
\hline V6 & Organizational culture & CO \\
\hline V7 & Training & TN \\
\hline V8 & Linking Six Sigma to employees & E \\
\hline V9 & Communication plan & ST \\
\hline V10 & Statistical thinking & IN \\
\hline V11 & Organizational infrastructure & SSBS \\
\hline V12 & Linking Six Sigma to business strategy & PSP \\
\hline V13 & Project prioritization and selection & AF \\
\hline V14 & Availability of funds & DC \\
\hline V15 & Qualitative data processing & \\
\hline
\end{tabular}

\subsection{Interpretive Structural Modelling (ISM)}

ISM was used to develop the linkages in the framework. This was done by using expert opinion, fitting the enablers into an ISM model and testing the model using MICMAC analysis.

\subsubsection{Expert opinion}

For the purpose of developing effective relationships, we prepared a blank Structural Self Interaction Matrix with a suitable closed-ended questionnaire. We held a brainstorming session, wherein the various issues related to Six Sigma implementation were discussed. The interdependence of the various critical success factors was established, to be further processed. Based on the brainstorming exercise, we completed the structural self-interaction matrix using the symbols V, A, X, and $\mathrm{O}$ as described by Mandal and Deshmukh, (1994); Soti et al. (2010); Sushil, (2012). After obtaining the SSIM matrix, it is further translated into a final reachability matrix. The next step is to assign levels to each of our identified antecedents. Once the reachability matrix is obtained, the reachability set and antecedent set for each of our antecedents is to be found. After identifying the enablers in these sets, the intersection set of these sets is found for all the enablers. The enablers for which the intersection set and the reachability set are same; the highest level of the ISM hierarchy is given to them. Now that the enablers of the highest level are identified, they are 
separated from the other enablers and iteration is repeated to identify the enablers in the next level. This iterative process is continues until levels of each enabler are found. In the next section we describe the interpretive structural modelling (ISM).

(Note: For further detailed explanation please refer to the Annex 1 where we provided detailed explanation for each steps involved in ISM modelling to help the readers to understand how final ISM model is obtained)

\subsection{Model using ISM}

Relationships with different antecedents have been categorized into different levels and the directions of relations have been shown by arrows. A single-ended arrow shows a single-way relationship (V \& A entries); double ended arrows show both way relationships (X Entry). This is known as a directed graph, which is transformed to an ISM model as shown in Figure 2.

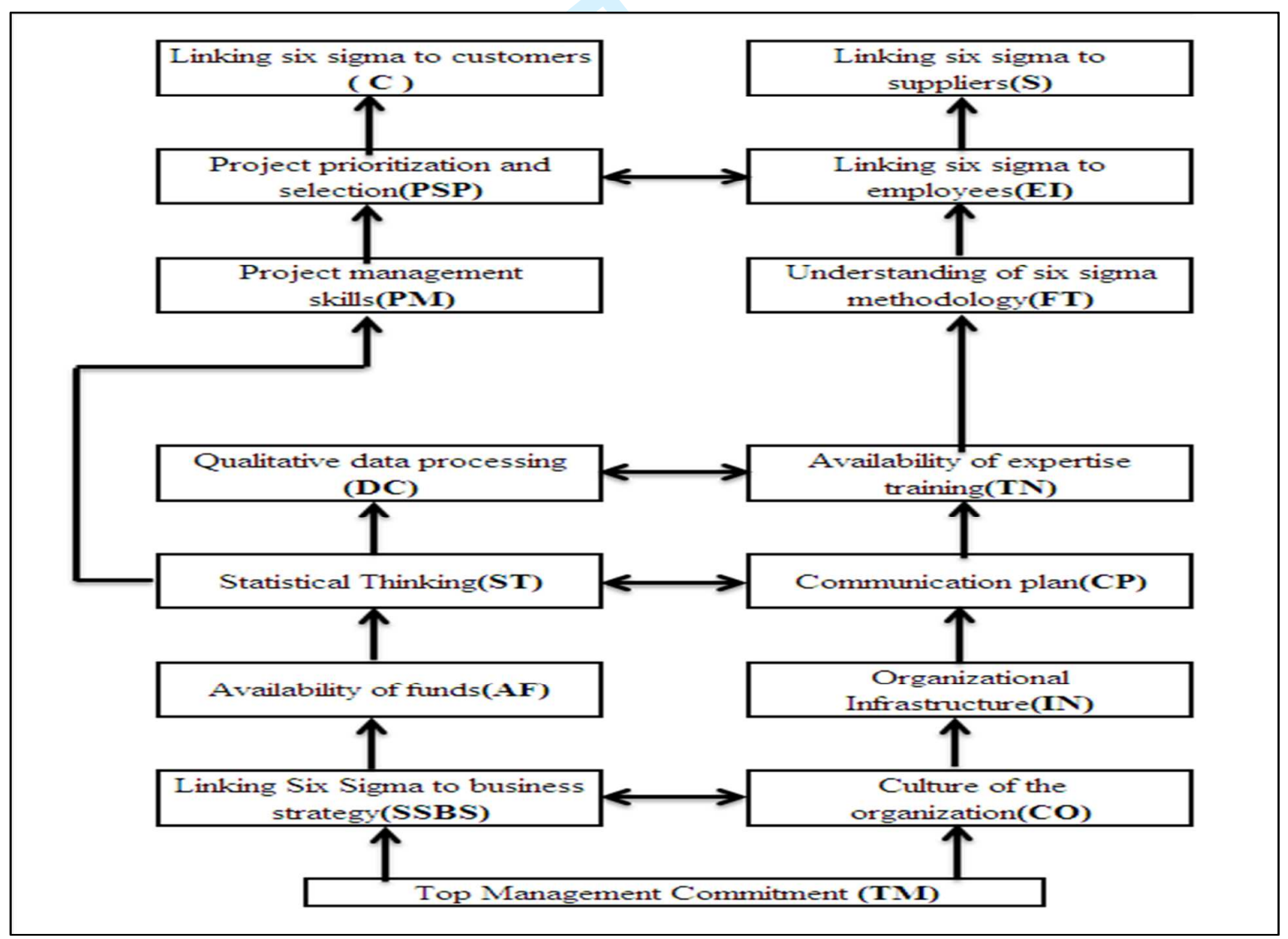

\section{Figure 2: ISM model}


The ISM model in Figure 2 shows that top management commitment (TMC), is the variable at the bottom level and linking Six Sigma to customers (C) \& linking Six Sigma to suppliers (S) are the top levels. It shows how TMC leads to $\mathrm{C} \& \mathrm{~S}$ through linking enablers. The present model is based on the views of a few experts, and it has its own limitations; however the merit of this model is its comprehensiveness. This model can further be analyzed to classify the enablers into four clusters using MICMAC analysis which we discuss in the next section.

\subsection{MICMAC Analysis "Matrice d'Impacts Croisés Multiplication Appliqués à un Classement"}

The method for impact matrix cross-reference multiplication applied to a classification is abbreviated as MICMAC. The objective of MICMAC analysis is to analyze the driving power and dependence of the enablers (Mandal and Deshmukh, 1994; Soti et al. 2010; Ali and Govindan, 2011). Based on the driving power and dependence the enablers have been classified into four clusters as:

Cluster 1: autonomous enablers;

Cluster 2: dependence enablers;

Cluster 3: linkage enablers;

Cluster 4: driving enablers

We have presented the four clusters of enablers in Figure 4. 


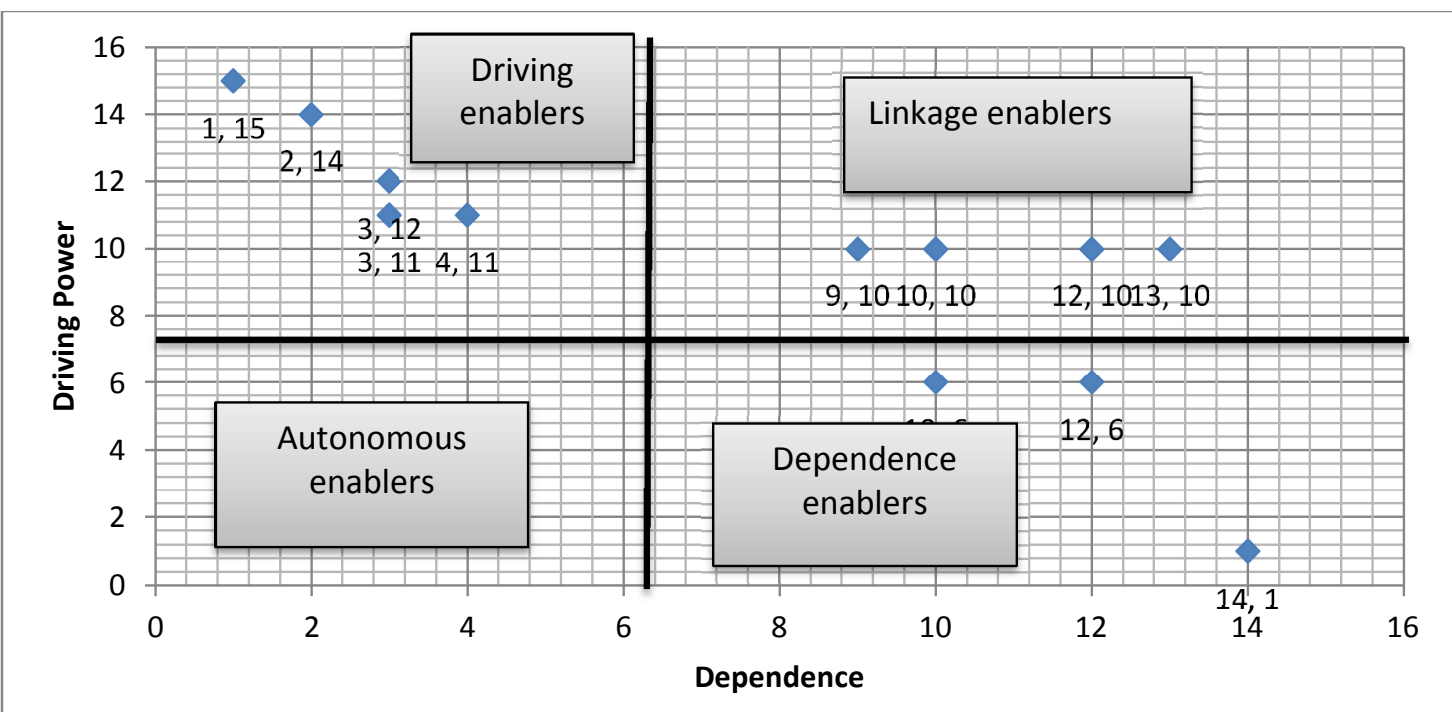

\section{Figure 3: Clusters of enablers}

In the present study we generated a scatter plot based on co-ordinates (De, DP); where De represents dependence and DP represent driving power. Based on the scatter plot we have further categorised the enablers into four clusters as identified in the preceding discussion. From the MICMAC analysis, we can see that top management commitment (TMC), linking Six Sigma with business strategy (SSBS), organizational culture (CO), availability of funds (AF) and organizational infrastructure (IN) have strong driving power and low dependence. Thus these enablers are located in cluster 4. The enablers statistical thinking (ST), availability of expertise training (TN), communication plan (CP) and project prioritization \& selection (PSP) have moderate dependence and moderate driving power. Thus these enablers are located in cluster 3. The enablers project management skills (PM), linking Six Sigma to employees (EI), qualitative data processing (DC), linking Six sigma to customers (C), linking Six Sigma to suppliers (S) and understanding Six Sigma methodology (FT) have poor driving power and strong dependence. These enablers are located in cluster 2 as shown in Figure 3. There were no Autonomous Enablers. In the next section we will discuss the synthesis of the ISM and MICMAC output to derive the final theoretical model. 


\subsection{Synthesis of ISM model and MICMAC analysis}

In this section we have synthesized the ISM model and the MICMAC output to generate the new theoretical framework. In the past researchers have either used literature review or alternative methods (e.g. case research, grounded theory, action research, ethnographic studies etc.) to generate theoretical frameworks. By linking enablers using the synthesis of an ISM model and MICMAC analysis output we can help to generate theory. In this study, the synthesis of ISM and MICMAC analysis resulted in a testable framework, as shown in Figure 4.

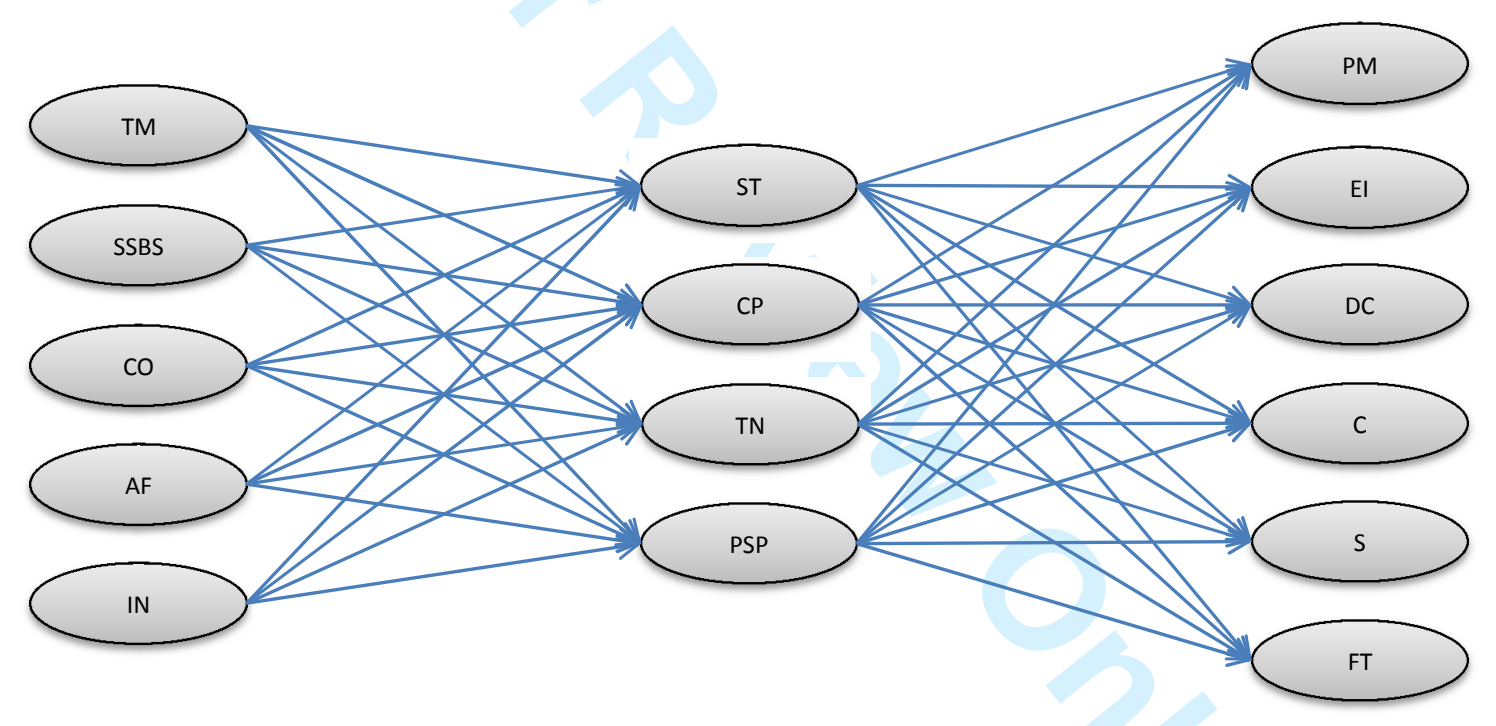

Figure 4: Theoretical Framework

The Six Sigma implementation framework shown in Figure 4 is a testable regression model in which the driving enablers are represented as independent variables. The linkage enablers are represented as mediating variables and the dependence enablers are represented as dependent variables. The framework satisfies Wacker's (1998) principles of good operations management theory, i.e. 
uniqueness, parsimony, conservation, generalizability, fecundity, internal consistency, empirical riskiness, and abstraction.

Hence we can argue that the foundation of our theoretical framework comprises of three elements: TMC, CO and AF. TMC supports human agency theory. The top management commitment helps in translating desired actions to achieve desired outcomes which include building project management skills, linking Six Sigma to employees, qualitative data processing, linking Six Sigma to customers. Linking Six Sigma to suppliers and understanding Six Sigma methodology through mediating variables like statistical thinking, communication plan, Six Sigma training, project prioritization \& selection. CO plays a significant role in achieving desired outcomes. AF supports resource based view theory. Resources include "assets, capabilities, organizational processes, firm attributes, information, and knowledge" and can be classified in terms of physical, human, or organizational capital (Barney, 1991). Human resources are regarded as one of the most important sources of competitive advantage as they are rare resources unlike physical capital (Hansen and Wernerfelt, 1989). It signifies that funds are one of the resources of the firm that can provide competitive advantage to the organization.

The SSBS and IF are significant drivers which can help to further achieve better desired results. Thus our present framework can be seen as a unique integration of three organizational theories.

\section{Research Design}

We now look at the research conducted to investigate and validate the theoretical framework. We deal with the measures used, the survey method and the respondents.

\subsection{Measures}

The measures used were adopted or modified from scales established in literature to avoid scale proliferation. We used multi-item measures of constructs in order to improve reliability, reduce measurement error, ensure greater variability among survey individuals, and improve validity (Churchill, 
1979). Each construct was operationalized using at least two items for effective measurement and analysis, applying confirmatory factor analysis (Gerbing and Anderson, 1988). All the items included in the survey instrument were pretested to ensure precise operationalization of defined variables. The constructs and their measures are shown in Table 3.

\section{Table 3: Constructs and their Indicators}

\begin{tabular}{|c|c|c|}
\hline Construct & Indicators & References \\
\hline \multirow[t]{4}{*}{$\begin{array}{l}\text { Top management } \\
\text { commitment (TMC) }\end{array}$} & $\begin{array}{l}\text { Our top management reviews quality policies and } \\
\text { strategy regularly }\end{array}$ & \multirow{4}{*}{$\begin{array}{c}\text { Jones et al. } \\
2010 ; \\
\text { Schroeder et } \\
\text { al. 2008; } \\
\text { Day, 2001 }\end{array}$} \\
\hline & $\begin{array}{l}\text { Our senior management is full of visionaries, they plan } \\
\text { for long term development of our company instead of } \\
\text { focusing on the short term profits }\end{array}$ & \\
\hline & $\begin{array}{l}\text { Our senior management is committed towards Six Sigma } \\
\text { practices }\end{array}$ & \\
\hline & $\begin{array}{l}\text { Managers of all departments have been involved in Six } \\
\text { Sigma projects }\end{array}$ & \\
\hline \multirow{5}{*}{$\begin{array}{l}\text { Understanding of } \\
\text { Six Sigma } \\
\text { methodology (FT) }\end{array}$} & $\begin{array}{l}\text { Our teams use Suppliers input process output customer } \\
\text { (SIPOC) methodology }\end{array}$ & \multirow{5}{*}{$\begin{array}{l}\text { Schroeder et } \\
\text { al. 2008; } \\
\text { Choo et al., } \\
\text { 2007a,b; } \\
\text { Pande et al. } \\
2000\end{array}$} \\
\hline & $\begin{array}{l}\text { Our teams use Failure mode effect analysis (FMEA) } \\
\text { methodology }\end{array}$ & \\
\hline & $\begin{array}{l}\text { Our teams use Fish bone analysis (Root cause analysis) } \\
\text { methodology }\end{array}$ & \\
\hline & $\begin{array}{l}\text { Our teams use Define Measure Analyse Improve Control } \\
\text { (DMAIC) approach }\end{array}$ & \\
\hline & $\begin{array}{l}\text { Our teams use Pareto chart in determining frequency of } \\
\text { possible causes }\end{array}$ & \\
\hline \multirow[t]{3}{*}{$\begin{array}{l}\text { Linking Six Sigma } \\
\text { to suppliers (S) }\end{array}$} & $\begin{array}{l}\text { We have been cooperating with our suppliers on a long } \\
\text { term basis }\end{array}$ & \multirow{3}{*}{$\begin{array}{l}\text { Antony and } \\
\text { Desai, } 2009\end{array}$} \\
\hline & $\begin{array}{l}\text { We have been providing clear specifications and } \\
\text { requirements to our suppliers }\end{array}$ & \\
\hline & $\begin{array}{l}\text { There is a supplier rating system to evaluate suppliers' } \\
\text { quality performance }\end{array}$ & \\
\hline \multirow[t]{3}{*}{$\begin{array}{l}\text { Linking Six Sigma } \\
\text { to customers (C) }\end{array}$} & $\begin{array}{l}\text { Our research and development department always has a } \\
\text { sound knowledge of the market trends and customer } \\
\text { requirements }\end{array}$ & \multirow{3}{*}{$\begin{array}{l}\text { Gosnik and } \\
\text { Vujica, } 2010\end{array}$} \\
\hline & $\begin{array}{l}\text { We have been working closely with the customers in } \\
\text { designing our products or improving the product design }\end{array}$ & \\
\hline & Our marketing staff is aware of and responsible for the & \\
\hline
\end{tabular}




\begin{tabular}{|c|c|c|}
\hline & $\begin{array}{l}\text { quality of the product and services that they provide to } \\
\text { the customers }\end{array}$ & \\
\hline & $\begin{array}{l}\text { We have been carrying out analysis of the customer } \\
\text { complaints or feedbacks in order to improve product } \\
\text { quality }\end{array}$ & \\
\hline Project management & Project team uses Six Sigma Project Charter & Brun,2011; \\
\hline & Our Project team understands its team roles & $\begin{array}{c}\text { Vujica, 2010; } \\
\text { Zhang et al. } \\
2008 ; \\
\text { Schroeder et } \\
\text { al. } 2008\end{array}$ \\
\hline $\begin{array}{l}\text { Culture of the } \\
\text { organization }(\mathrm{CO})\end{array}$ & $\begin{array}{l}\text { I'm having clarity regarding as to how Six Sigma will } \\
\text { improve my efficiency }\end{array}$ & \\
\hline & $\begin{array}{l}\text { I'm continuously motivated by my superior to follow Six } \\
\text { Sigma systems, processes and guidelines }\end{array}$ & \\
\hline & $\begin{array}{l}\text { I'm unable to deliver much, if I adhere to systems, } \\
\text { processes and guidelines of Six Sigma }\end{array}$ & $\begin{array}{l}\text { Gosnik and } \\
\text { Vujica, } 2010\end{array}$ \\
\hline & $\begin{array}{l}\text { Senior Employees (Manager and above) have a clear } \\
\text { vision } \\
\text { regarding Six Sigma }\end{array}$ & \\
\hline $\begin{array}{l}\text { Availability of } \\
\text { expertise training } \\
\text { (TN) }\end{array}$ & $\begin{array}{l}\text { I'm having a mentor assigned to train and counsel me } \\
\text { about Six Sigma }\end{array}$ & \\
\hline & $\begin{array}{l}\text { Regular Six Sigma related trainings and workshops are } \\
\text { organized at my workplace }\end{array}$ & \\
\hline & I'm encourraced to take un Six Sioma certification & $\begin{array}{l}\text { Sot1 et al. } \\
(2010)\end{array}$ \\
\hline & $\begin{array}{l}\text { There is a highly qualified Six Sigma personnel assigned } \\
\text { to each department }\end{array}$ & \\
\hline $\begin{array}{l}\text { Linking Six Sigma } \\
\text { to employees (EI) }\end{array}$ & $\begin{array}{l}\text { Employees understand the need for implementing Six } \\
\text { Sigma }\end{array}$ & \\
\hline & Employees are aware of what they need to change & $\begin{array}{l}\text { Vujica, 2010; } \\
\text { Schroeder et } \\
\text { al. } 2008\end{array}$ \\
\hline & Employees are eager to participate in Six Sigma projects & \\
\hline
\end{tabular}




\subsection{Survey method and respondents}

Data was collected using a survey that was distributed electronically. We used a two-stage data collection approach that included pre-testing and testing the survey (Malhotra and Grover, 1998). A pre-test was conducted with 24 academics and business professionals following personal discussions on proposed survey questions. Based on the results of the discussions, the survey questions were adjusted accordingly; the goal was to ensure the questions were understandable and not vague, ambiguous, or difficult to answer (Dillman 2000). Furthermore the questions were confirmed to be specific enough to convey clear meaning to survey respondents, appropriate in length, and not biased (Converse and Presser, 1986).

The initial sample frame consisted of 213 firms and was compiled from databases provided by the city of Nashik Industries \& Manufacturers Association (NIMA) and the Confederation of Indian Industries (CII). The databases were chosen to reach a high number of executives of sufficient 
seniority and knowledge to answer questions related to the survey. We were mainly interested in manufacturing firms, because of their vital importance to the GDP of India. Also, this was where a good level of experience would be expected, since manufacturing firms were the first to implement Six Sigma in India. Data collection was conducted following a modified version of Dillman's (2007) total design method. We sent the survey to potential respondents as a pdf version in an email attachment, followed up with phone calls. Depending upon the preference of the respondents, surveys were answered via e-mail, fax, or mail. Overall, we received 115 complete and usable responses. This represents a response rate of $54.9 \%$, which can be considered good for empirical studies of this nature. The sample size is sufficient for studying the hypotheses developed in this study (Hair et al.1995), and is comparable to response rates achieved in recent research on operations \& supply chain management research such as Schoenherr and Mabert, 2008; or Braunscheidel and Suresh, 2009. As the questionnaire is the part of a major research project, the total length of the survey was quite long ( 6 pages), which may have been off-putting to some potential respondents. Furthermore, firms are increasingly adopting policies to not engage in external surveys, as we were told in follow-up phone calls to non-respondents.

Of our respondents, over 9\% belong to the top management cadre and the remainder belong to middle and low management levels. $8 \%$ of the respondents have black belt and $36 \%$ of the respondents have green belt. The rest includes respondents who are preparing for green belt certification and most of them do not possess any of these certifications. Over $71 \%$ of the respondents were between 25 years to 40 years of age and only $5 \%$ of the respondents were over 50 years of age.

\subsection{Non-response bias}

In any survey, non-response bias can emerge as an important factor impacting the final result and, put simply, it is nothing but the difference between the answers of respondents and non-respondents (Lambert and Harrington, 1990). In our study, data was collected in a span of three weeks and around fifty two responses were received in the last days of data collection. 
Thus, it was of prime importance to check the non-response bias and as a convention, the responses of early and late waves of returned surveys were compared (Krause et al., 2001; Narasimhan and Das, 2001; Stanley and Wisner, 2001; Lambert and Harrington, 1990). A pair wise $t$-test was carried out and the final sample was split into two, depending on the dates they were received. The early wave group consisted of 71 responses while the late wave group consisted of 52 responses. The $t$-tests performed on the responses for the "top management" and "frequency of Six Sigma tools used" construct of these two groups yielded a p value of 0.511 and 0.184 respectively. Similarly, the other constructs show that non-response bias is not an issue in our study.

\subsection{Statistical checks}

Before evaluating the reliability and validity of the measurement items, the indicators were tested for the assumptions of constant variance, existence of outliers, and normality. We used plots of residuals by predicted values and statistics of skewness and kurtosis. To detect multivariate outliers, we used Mahalanobis distances of predicted values (e.g. Cohen et al. 2003). The maximum absolute value of skewness is $<2$ and maximum value of kurtosis is $<7$. It suggests that the statistics were well within defined limits (Curran et al, 1996). Finally, neither the plots nor the statistics indicated any significant deviances from the assumption.

To ensure multicollinearity is not a problem, we calculated variance inflation factors (VIF). All VIFs were found to be less than 1.5 and therefore considerably lower than the recommended threshold of 4 (Hair et al, 1995). We used confirmatory factor analysis (CFA) to establish convergent validity and unidimensionality of factors. These are discussed in detail later.

\section{Reliability and Validity Test}

\section{1 Reliability test}

Calculation of Cronbach alpha is the default analysis that can be used to check the consistency of the question scales used to collect data. Any value of 
Cronbach alpha greater than 0.6 is acceptable and alpha values substantial lower indicate an unreliable scale (Nunnally, 1978). The value of alpha depends on the number of items on the scale and does not mean that the scale is highly reliable. We have found that our questionnaire and their measures are consistent. Cronbach alpha values are shown in Table 4.

Table 4. Cronbach Alpha Test

\begin{tabular}{|c|c|c|c|}
\hline Description & $\begin{array}{c}\text { Number of items } \\
\text { (before FA) }\end{array}$ & $\begin{array}{c}\text { Number of } \\
\text { items } \\
\text { (after FA) }\end{array}$ & $\begin{array}{c}\text { Cronbach- } \\
\text { Alpha }\end{array}$ \\
\hline Top Management Commitment (TMC) & 4 & 4 & 0.78 \\
\hline Understanding of Six Sigma methodology (FT) & 5 & 5 & 0.87 \\
\hline Linking Six Sigma to suppliers (S) & 3 & 2 & 0.76 \\
\hline Linking Six Sigma to customers (C) & 4 & 3 & 0.67 \\
\hline Project management skills (PM) & 2 & 2 & 0.78 \\
\hline Culture of the organization (CO) & 4 & 2 & 0.71 \\
\hline Availability of expertise training (TN) & 4 & 4 & 0.80 \\
\hline Linking Six Sigma to employees (EI) & 5 & 5 & 0.74 \\
\hline Communication plan (CP) & 3 & 3 & 0.69 \\
\hline Statistical Thinking (ST) & 3 & 3 & 0.79 \\
\hline Qualitative data processing (DC) & 2 & 2 & 0.83 \\
\hline Availability of funds (AF) & 3 & 3 & 0.75 \\
\hline Linking Six Sigma to business strategy (SSBS) & 4 & 3 & 0.79 \\
\hline Project prioritization and selection (PSP) & 3 & 3 & 0.74 \\
\hline Organizational Infrastructure (IN) & 4 & 4 & 0.71 \\
\hline
\end{tabular}

\section{2 Unidimensionality}

Assessing unidimensionality means determining whether a set of indicators reflect one, as opposed to more than one, concerned factor (Gerbing and Anderson, 1988). There are two implicit conditions for establishing unidimensionality. First, an empirical item must be significantly associated with the representation of a latent construct; this is achieved by suppressing the factor loadings below 0.5; and second, it must be associated with one and only one construct which can be validated by discriminant validity (e.g. Anderson and Gerbing, 1982; Phillips and Bagozzi, 1986; Hair et al., 1995). A measure must satisfy both of these conditions in order to be considered unidimensional. 


\section{3 Validity tests}

We took steps to assure content validity, construct validity, convergent validity and discriminant validity.

Content validity is Pre-testing the measurement instrument before the collection of data was further validation of the content. Several industry experts were asked to review the questionnaire and validate the content (Dillman, 1978). The final survey instrument incorporated minor changes to remove the ambiguities that were discovered during this validation process. These tests indicated that the resulting measurement instrument represented the content of the Six Sigma success factors.

Construct validity is the extent to which the items in a scale measure the latent construct. Testing of construct validity concentrates on segregating items with factor loadings greater than 0.5 and it also validates the fact no item loading is discriminant to other latent constructs.

Convergent validity measures the convergence of each item loading on the latent construct it is measuring. In this study, convergent validity was assessed using CFA. In the Table 5, it can be seen that the composite reliability (CR) is greater than the average variance extracted (AVE).

Table 5: Convergent validity

\begin{tabular}{|c|c|c|c|c|}
\hline Construct & Indicators & Factor Loadings & AVE & $\mathrm{CR}$ \\
\hline \multirow{4}{*}{ TMC } & TM1 & 0.73 & \multirow{4}{*}{0.61} & \multirow{4}{*}{0.86} \\
\hline & TM2 & 0.73 & & \\
\hline & TM3 & 0.87 & & \\
\hline & TM4 & 0.78 & & \\
\hline \multirow{5}{*}{ FT } & FT1 & 0.83 & \multirow{5}{*}{0.68} & \multirow{5}{*}{0.91} \\
\hline & FT2 & 0.83 & & \\
\hline & FT3 & 0.86 & & \\
\hline & FT4 & 0.81 & & \\
\hline & FT5 & 0.8 & & \\
\hline \multirow{2}{*}{$\mathrm{S}$} & $\mathrm{S} 1$ & 0.76 & \multirow{2}{*}{0.59} & \multirow{2}{*}{0.74} \\
\hline & $\mathrm{S} 2$ & 0.77 & & \\
\hline $\mathrm{C}$ & $\mathrm{C} 1$ & 0.72 & 0.61 & 0.82 \\
\hline
\end{tabular}




\begin{tabular}{|c|c|c|c|c|}
\hline & $\mathrm{C} 2$ & 0.8 & & \\
\hline & C3 & 0.82 & & \\
\hline \multirow{2}{*}{$\mathrm{PM}$} & PM1 & 0.84 & \multirow{2}{*}{0.71} & \multirow{2}{*}{0.83} \\
\hline & PM2 & 0.84 & & \\
\hline \multirow{2}{*}{$\mathrm{CO}$} & $\mathrm{CO} 1$ & 0.9 & \multirow{2}{*}{0.78} & \multirow{2}{*}{0.87} \\
\hline & $\mathrm{CO} 2$ & 0.86 & & \\
\hline \multirow{4}{*}{ TN } & TN1 & 0.77 & \multirow{4}{*}{0.63} & \multirow{4}{*}{0.87} \\
\hline & TN2 & 0.85 & & \\
\hline & TN3 & 0.8 & & \\
\hline & TN4 & 0.76 & & \\
\hline \multirow{5}{*}{$\mathrm{EI}$} & EI1 & 0.74 & \multirow{5}{*}{0.51} & \multirow{5}{*}{0.84} \\
\hline & EI2 & 0.78 & & \\
\hline & EI3 & 0.8 & & \\
\hline & EI4 & 0.67 & & \\
\hline & EI5 & 0.56 & & \\
\hline \multirow{3}{*}{$\mathrm{CP}$} & CP1 & 0.78 & \multirow{3}{*}{0.58} & \multirow{3}{*}{0.64} \\
\hline & $\mathrm{CP} 2$ & 0.85 & & \\
\hline & CP3 & 0.64 & & \\
\hline \multirow{3}{*}{ ST } & ST1 & 0.78 & \multirow{3}{*}{0.54} & \multirow{3}{*}{0.78} \\
\hline & ST2 & 0.74 & & \\
\hline & ST3 & 0.68 & & \\
\hline \multirow{2}{*}{$\mathrm{DC}$} & $\mathrm{DC} 1$ & 0.83 & \multirow{2}{*}{0.69} & \multirow{2}{*}{0.82} \\
\hline & DC2 & 0.83 & & \\
\hline \multirow{3}{*}{$\mathrm{AF}$} & $\mathrm{AF} 1$ & 0.6 & \multirow{3}{*}{0.53} & \multirow{3}{*}{0.77} \\
\hline & $\mathrm{AF} 2$ & 0.79 & & \\
\hline & AF3 & 0.78 & & \\
\hline \multirow{3}{*}{ SSBS } & SSBS1 & 0.74 & \multirow{3}{*}{0.48} & \multirow{3}{*}{0.73} \\
\hline & SSBS2 & 0.76 & & \\
\hline & SSBS3 & 0.55 & & \\
\hline \multirow{3}{*}{$\mathrm{PSP}^{*}$} & PSP1 & 0.66 & \multirow{3}{*}{0.40} & \\
\hline & PSP2 & 0.62 & & 0.66 \\
\hline & PSP3 & 0.61 & & \\
\hline & IN1 & 0.82 & & \\
\hline INI & IN2 & 0.78 & 50 & 70 \\
\hline $11 \mathrm{~N}$ & IN3 & 0.64 & 0.50 & 0.19 \\
\hline & IN4 & 0.54 & & \\
\hline
\end{tabular}

URL: https://mc.manuscriptcentral.com/ctqm Email: eskildsen@asb.dk 
From Table 5 we can draw conclusion that all the constructs except PSP* the AVE and SCR are well above minimum cut of values (i.e. SCR $\geq 0.7$ and AVE $\geq 0.5$ ) suggested by Fornell and Larcker (1981).

Discriminant validity measures the extent to which the individual item loadings of a latent construct are unique and do not significantly measure other latent constructs. In this study, discriminant validity was established using CFA. In discriminant validity, an item is able to account for more variance in the observed variables associated with it than a) measurement error or similar external, unmeasured influences; or b) other constructs within the conceptual framework. If this is not the case, then the validity of the individual indicators and of the construct is questionable (Fornell and Larcker, 1981). Shared variance is the other name for discriminant validity. The amount of variance that a variable (construct) is able to explain in another variable (construct) is identified as shared variance. Mathematically, it is the square of the correlation between any two constructs. Independent variables share some of their predictive power over dependent variables in case of correlation between the independent variables (Hair et al. 1995). In our study bivariate correlation analysis was conducted and the diagonal elements were the square root of the average variance extracted (AVE). All the correlation coefficients are less than the AVE, hence we concluded that our construct possessed discriminant validity as shown in Table 6.

Table 6: Inter-correlation Matrix

\begin{tabular}{|c|c|c|c|c|c|c|c|c|c|c|c|c|c|c|c|}
\hline & TMC & FT & $\mathrm{S}$ & $\mathrm{C}$ & $\mathrm{PM}$ & $\mathrm{CO}$ & TN & EI & $\mathrm{CP}$ & ST & $\mathrm{DC}$ & $\mathrm{AF}$ & SSBS & PSP & IN \\
\hline TMC & $0.78^{*}$ & & & & & & & & & & & 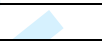 & & & \\
\hline FT & 0.36 & $0.83^{*}$ & & & & & & & & & $V$ & 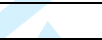 & & & \\
\hline $\mathrm{S}$ & 0.36 & 0.66 & $0.76^{*}$ & & & & & & & & $V$ & 4 & & & \\
\hline $\mathrm{C}$ & 0.61 & 0.56 & 0.59 & $0.78^{*}$ & & & & & & & & & & & \\
\hline $\mathrm{PM}$ & 0.53 & 0.63 & 0.45 & 0.62 & $0.91^{*}$ & & & & & & & & & & \\
\hline $\mathrm{CO}$ & 0.31 & 0.58 & 0.48 & 0.41 & 0.45 & $0.84^{*}$ & & & & & & & & & \\
\hline TN & 0.46 & 0.71 & 0.42 & 0.43 & 0.53 & 0.56 & 0.88* & & & & & & & & \\
\hline EI & 0.65 & 0.29 & 0.37 & 0.56 & 0.36 & 0.28 & 0.37 & $0.92^{*}$ & & & & & & & \\
\hline $\mathrm{CP}$ & 0.38 & 0.36 & 0.35 & 0.57 & 0.52 & 0.39 & 0.5 & 0.44 & $0.84^{*}$ & & & & & & \\
\hline ST & 0.65 & 0.45 & 0.49 & 0.63 & 0.48 & 0.32 & 0.5 & 0.6 & 0.54 & $0.88^{*}$ & & & & & \\
\hline $\mathrm{DC}$ & 0.27 & 0.36 & 0.25 & 0.29 & 0.25 & 0.35 & 0.4 & 0.34 & 0.41 & 0.35 & 0.80* & & & & \\
\hline $\mathrm{AF}$ & 0.51 & 0.47 & 0.35 & 0.43 & 0.49 & 0.23 & 0.58 & 0.41 & 0.5 & 0.47 & 0.24 & $0.73^{*}$ & & & \\
\hline SSBS & 0.48 & 0.58 & 0.41 & 0.56 & 0.58 & 0.39 & 0.66 & 0.45 & 0.56 & 0.59 & 0.39 & 0.62 & $0.69 *$ & & \\
\hline PSP & 0.41 & 0.23 & 0.44 & 0.47 & 0.27 & 0.34 & 0.33 & 0.47 & 0.39 & 0.41 & 0.28 & 0.13 & 0.39 & $0.63^{*}$ & \\
\hline IN & 0.37 & 0.49 & 0.5 & 0.53 & 0.38 & 0.41 & 0.46 & 0.46 & 0.45 & 0.53 & 0.36 & 0.33 & 0.51 & 0.42 & $0.70 *$ \\
\hline
\end{tabular}


(* represent $\sqrt{ }(\mathrm{AVE}))$

\section{Findings}

Following the statistical tests, we are able to state that the framework shown in Figure 4 is supported by analysis of the responses from industry. Enablers of Six Sigma implementation fall into three categories: the Drivers (top management commitment (TMC), linking Six Sigma with business strategy (SSBS), organizational culture (CO), availability of funds (AF) and organizational infrastructure (IN)); The Linking enablers (statistical thinking (ST), availability of expertise training (TN), communication plan (CP) and project prioritization \& selection (PSP)); and the Dependence enablers (project management skills (PM), linking Six Sigma to employees (EI), qualitative data processing (DC), linking Six Sigma to customers (C), linking Six Sigma to suppliers (S) and understanding Six Sigma methodology (FT)). Use of the ISM with MICMAC validates these groupings and indicates the order of precedence between the enablers, leading to a tentative priority for implementation.

\subsection{Discussion}

The present study further supports several of the past studies (e.g. Linderman et al, 2006; Schroeder et al, 2008; Zu et al, 2010; Shafer and Moeller, 2012; Easton and Rosenzweig, 2012; Arumugam et al, 2013). As complexity increases, firms find it more difficult to plan and predict their organizational actions, which appears to include projects such as Six Sigma implementation. It is pertinent for firms to be sensitive and responsive to their environments with co-evolution and their interdependencies in adapting to the system (Crozier and Thoenig, 1976). The findings of our research further supports Monteiro de Carvalho et al. (2014) studies in context to Brazilian companies. The present study furthers Monteiro de Carvalho et al. (2014) study by identifying the mediating role played by training in successful implementation of Six Sigma program.

\section{Conclusions}

Our interest in exploring the enablers of Six Sigma implementation and their contextual relationship was triggered by two facets of the Six Sigma 
implementation process in Indian manufacturing organizations: first, the scarcity of studies on enablers of Six Sigma implementation and second, the lack of theory building articles. In recent years we have noted a significant rise in alternative methods for theory building (Ketokivi and Choi, 2014). Markman and Krause (2014) have further argued that the use of rationalist approaches such as survey methodology and operations research field generally limit the scope of the study. On the other hand, as noted previously, Aldag and Stearns (1998) have argued that the qualitative research methods lack reliability and validity. Under these circumstances, we argued that to generate comprehensive theory we need to embrace mixed research design.

In an attempt to meet our first research objective, we used a systematic review of literature followed by a review of expert opinion to outline 15 enablers of Six Sigma implementation. Further, we used the ISM technique to develop the contextual relationships among these enablers, which was underdeveloped in the literature. To categorize these variables into four clusters, we have performed MICMAC analysis which uses two determinants (i.e. dependence power and driving power) to categorize these fifteen enablers into four clusters. The MICMAC analysis has further resolved doubt related to nature of the enablers. To further past research we have extended the ISM literature by synthesizing the ISM and MICMAC output in generating the theoretical framework. Second, the present study uniquely contributes to "resource based view (RBV)" theory in showing the role of resources in the implementation framework.

\section{Limitations of present study}

Like all studies, this present study has its limitations and future studies are needed to develop the full benefits from this work. Most importantly, the sample on which the study was conducted was not designed with the intention to generalize the results to the whole population to which the samples belong (Cooper and Schindler, 2001). Not all sampling techniques allow this generalization. The most known, comprehensive and pervasive technique is perhaps the simple random sampling in which each possible sample of a given size is equally likely to be the one selected. By basing the study on experienced 
managers in manufacturing industry in India we offer a strong base but cultural, economic and other factors may mean that different results may be found in other industries or locations.

\section{Recommendations for future research}

While this study was able to provide additional insight into enablers of Six Sigma implementation and their contextual relationships, it also revealed areas that would benefit from further research. Future research could thus focus on the other dimensions. By doing so, a better and fuller understanding on the effects of enablers on organizational performance may be achieved. Each of these dimensions can be explored further using single dimension and its effect on organizational performance.

Second, there is a strong need for longitudinal research. A longitudinal analysis of companies over time would provide data to address at least three research questions:

(1) Is there a time lag between investing in Six Sigma and achieving an expected performance?

(2) Does the structure identified in this research lead to a particular order in which these investments should be made? and

(3) How does performance compare before and after Six Sigma implementation?

Another way forward is to extend this research to analyse enablers on the basis of individual success stories of Six Sigma implementation among selected organizations. Similar analysis can be carried out in other countries as well to explore the similarities of success factors of Six Sigma in different national settings. Further work will increase the sample size to validate the study more broadly. The success factors examined in this study are not absolute factors because they look back at the outcome of the transformation which concerned organizations have observed after Six Sigma implementation. A number of semi-structured interviews with Black belts, Six Sigma champions and Master Black Belts in the next phase of this study would further refine the results of this research, and it would be useful to do this during Six-Sigma 
implementations to derive a more detailed picture. In future, 'big data and predictive analytics' may be used for generating more comprehensive Six Sigma theory. Last but very important for advancing operations management research and Six Sigma field is to focus on alternative methods such as action research.

Our study has gone some way to answer the long-standing demand for a comprehensive framework which helps to address the complex need of the industry. We hope future research will add to this work.

\section{Acknowledgments:}

The authors are most grateful to anonymous reviewers for their extremely constructive and helpful comments which helped to improve the presentation of the paper considerably. 


\section{ANNEX 1}

\section{Note:}

\section{Structural Self Identification Matrix (SSIM)}

Relationship between any two antecedent means if any antecedent helps to achieve another. The direction relationship between two antecedents $(i, j)$ is then derived by using following notations:

i. V Entry - If antecedent ' $\mathrm{i}$ ' helps in achieving antecedent ' $\mathrm{j}$ ' and the reverse is not true.

ii. A Entry - If antecedent ' $j$ ' helps in achieving antecedent ' $i$ ' and the reverse is not true.

iii. $\mathbf{X}$ Entry - If both antecedents help in achieving each other; they are both ways related

iv. O Entry - If neither of the antecedents helps in achieving either of them; they are unrelated

We have prepared SSIM matrix based on experts input as shown in Table 7.

Table 7: Structural self-iteration matrix

\begin{tabular}{|c|c|c|c|c|c|c|c|c|c|c|c|c|c|c|c|c|}
\hline \multirow{2}{*}{\multicolumn{2}{|c|}{ SSIM }} & TMC & $F T$ & $S$ & $C$ & $P M$ & $\mathrm{CO}$ & $T N$ & $E I$ & $C P$ & $S T$ & $I N$ & SSBS & PSP & $A F$ & $D C$ \\
\hline & & 1 & 2 & 3 & 4 & 5 & 6 & 7 & 8 & 9 & 10 & 11 & 12 & 13 & 14 & 15 \\
\hline$T M C$ & 1 & 1 & V & $\mathrm{V}$ & $\mathrm{V}$ & $\mathrm{O}$ & V & $\mathrm{V}$ & $\mathrm{V}$ & $\mathrm{V}$ & $\mathrm{O}$ & $\mathrm{V}$ & $\mathrm{V}$ & $\mathrm{O}$ & V & $\mathrm{O}$ \\
\hline$F T$ & 2 & A & 1 & $\mathrm{~V}$ & $\mathrm{~V}$ & $\mathrm{O}$ & A & A & A & A & A & A & A & $\mathrm{V}$ & A & A \\
\hline$S$ & 3 & A & A & 1 & $\mathrm{O}$ & $\mathrm{O}$ & A & $\mathrm{O}$ & $\mathrm{O}$ & A & $\mathrm{O}$ & $\mathrm{O}$ & A & A & $\mathrm{O}$ & A \\
\hline$C$ & 4 & A & A & $\mathrm{O}$ & 1 & $\mathrm{O}$ & A & $\mathrm{O}$ & $\mathrm{O}$ & A & A & $\mathrm{O}$ & A & A & $\mathrm{O}$ & A \\
\hline$P M$ & 5 & $\mathrm{O}$ & $\mathrm{O}$ & $\mathrm{O}$ & $\mathrm{O}$ & 1 & A & A & $\mathrm{O}$ & $\mathrm{O}$ & $\mathrm{O}$ & A & A & $\mathrm{V}$ & $\mathrm{O}$ & $\mathrm{O}$ \\
\hline $\mathrm{CO}$ & 6 & A & $\mathrm{V}$ & $\mathrm{V}$ & $\mathrm{V}$ & $\mathrm{V}$ & 1 & $\mathrm{~V}$ & $\mathrm{~V}$ & $\mathrm{~V}$ & $\mathrm{~V}$ & $\mathrm{~V}$ & $\mathrm{~A}$ & $\mathrm{~V}$ & $\mathrm{O}$ & $\mathrm{V}$ \\
\hline$T N$ & 7 & A & $\mathrm{V}$ & $\mathrm{O}$ & $\mathrm{O}$ & $\mathrm{V}$ & A & 1 & $\mathrm{~V}$ & A & $\mathrm{V}$ & A & A & $\mathrm{V}$ & A & A \\
\hline$E \boldsymbol{I}$ & 8 & A & $\mathrm{V}$ & $\mathrm{O}$ & $\mathrm{O}$ & $\mathrm{O}$ & A & A & 1 & A & $\mathrm{O}$ & A & A & A & $\mathrm{O}$ & $\mathrm{O}$ \\
\hline $\boldsymbol{C P}$ & 9 & A & $\mathrm{V}$ & $\mathrm{V}$ & $\mathrm{V}$ & $\mathrm{O}$ & A & $\mathrm{V}$ & $\mathrm{V}$ & 1 & $\mathrm{O}$ & $\mathrm{O}$ & A & A & $\mathrm{O}$ & $\mathrm{O}$ \\
\hline$S T$ & 10 & $\mathrm{O}$ & $\mathrm{V}$ & $\mathrm{O}$ & $\mathrm{V}$ & $\mathrm{O}$ & A & A & $\mathrm{O}$ & $\mathrm{O}$ & 1 & A & A & $\mathrm{O}$ & $\mathrm{O}$ & $\mathrm{V}$ \\
\hline$I N$ & 11 & A & $\mathrm{V}$ & $\mathrm{O}$ & $\mathrm{O}$ & $\mathrm{V}$ & A & $\mathrm{V}$ & $\mathrm{V}$ & $\mathrm{O}$ & $\mathrm{V}$ & 1 & A & $\mathrm{O}$ & $\mathrm{O}$ & $\mathrm{V}$ \\
\hline SSBS & 12 & A & $\mathrm{V}$ & $\mathrm{V}$ & $\mathrm{V}$ & $\mathrm{V}$ & $\mathrm{V}$ & $\mathrm{V}$ & $\mathrm{V}$ & $\mathrm{V}$ & $\mathrm{V}$ & $\mathrm{V}$ & 1 & $\mathrm{~V}$ & $\mathrm{~V}$ & $\mathrm{~V}$ \\
\hline PSP & 13 & $\mathrm{O}$ & A & $\mathrm{V}$ & $\mathrm{V}$ & A & A & A & $\mathrm{V}$ & $\mathrm{V}$ & $\mathrm{O}$ & $\mathrm{O}$ & A & 1 & $\mathrm{O}$ & A \\
\hline$A F$ & 14 & $\mathrm{~A}$ & V & $\mathrm{O}$ & $\mathrm{O}$ & $\mathrm{O}$ & $\mathrm{O}$ & $\mathrm{V}$ & $\mathrm{O}$ & $\mathrm{O}$ & $\mathrm{O}$ & $\mathrm{O}$ & A & $\mathrm{O}$ & 1 & $\mathrm{O}$ \\
\hline$D C$ & 15 & $\mathrm{O}$ & $\mathrm{V}$ & $\mathrm{V}$ & $\mathrm{V}$ & $\mathrm{O}$ & A & $\mathrm{V}$ & $\mathrm{O}$ & $\mathrm{O}$ & A & A & A & $\mathrm{V}$ & $\mathrm{O}$ & 1 \\
\hline
\end{tabular}




\section{Initial Reachability Matrix}

The SSIM is then transformed into a simpler binary matrix using binary notation in place of $\mathrm{V}, \mathrm{A}, \mathrm{X}$ and $\mathrm{O}$. The binary substitution of $\mathrm{V}, \mathrm{A}, \mathrm{X}$ and $\mathrm{O}$ follows the following steps:

i. If the relation of the $(i, j)$ cell in SSIM is $V$, then $(i, j)$ in the initial reachability matrix is taken as 1 and $(j, i)$ cell is taken as 0 .

ii. If the relation of the $(i, j)$ cell in SSIM is $A$, then $(i, j)$ in the initial reachability matrix is taken as 0 and $(\mathrm{j}, \mathrm{i})$ cell is taken as 1 .

iii. If the relation of the cell $(i, j)$ cell in SSIM is taken as $X$, then $(i, j)$ in the initial reachability matrix is taken as 1 and $(\mathrm{j}, \mathrm{i})$ cell is also taken as 1 .

iv. If the relation of the $(i, j)$ cell in SSIM is taken as $O$, then $(i, j)$ in the initial reachability matrix is taken as 0 and $(j, i)$ cell is also taken as 0 .

We have derived initial reachability matrix as shown in Table 8 based on inputs from $\mathrm{i}$ to iv.

\section{Table 8: Initial reachability matrix}

\begin{tabular}{|c|c|c|c|c|c|c|c|c|c|c|c|c|c|c|c|c|}
\hline & & $\mathbf{1}$ & $\mathbf{2}$ & $\mathbf{3}$ & $\mathbf{4}$ & $\mathbf{5}$ & $\mathbf{6}$ & $\mathbf{7}$ & $\mathbf{8}$ & $\mathbf{9}$ & $\mathbf{1 0}$ & $\mathbf{1 1}$ & $\mathbf{1 2}$ & $\mathbf{1 3}$ & $\mathbf{1 4}$ & $\mathbf{1 5}$ \\
\hline $\boldsymbol{T M C}$ & $\mathbf{1}$ & 1 & 1 & 1 & 1 & 0 & 1 & 1 & 1 & 1 & 0 & 1 & 1 & 0 & 1 & 0 \\
\hline $\boldsymbol{F T}$ & $\mathbf{2}$ & 0 & 1 & 1 & 1 & 0 & 0 & 0 & 0 & 0 & 0 & 0 & 0 & 1 & 0 & 0 \\
\hline $\mathbf{S}$ & $\mathbf{3}$ & 0 & 0 & 1 & 0 & 0 & 0 & 0 & 0 & 0 & 0 & 0 & 0 & 0 & 0 & 0 \\
\hline $\boldsymbol{C}$ & $\mathbf{4}$ & 0 & 0 & 0 & 1 & 0 & 0 & 0 & 0 & 0 & 0 & 0 & 0 & 0 & 0 & 0 \\
\hline $\boldsymbol{P M}$ & $\mathbf{5}$ & 0 & 0 & 0 & 0 & 1 & 0 & 0 & 0 & 0 & 0 & 0 & 0 & 1 & 0 & 0 \\
\hline $\boldsymbol{C O}$ & $\mathbf{6}$ & 0 & 1 & 1 & 1 & 1 & 1 & 1 & 1 & 1 & 1 & 1 & 0 & 1 & 0 & 1 \\
\hline $\boldsymbol{T N}$ & $\mathbf{7}$ & 0 & 1 & 0 & 0 & 1 & 0 & 1 & 1 & 0 & 1 & 0 & 0 & 1 & 0 & 0 \\
\hline $\boldsymbol{E I}$ & $\mathbf{8}$ & 0 & 1 & 0 & 0 & 0 & 0 & 0 & 1 & 0 & 0 & 0 & 0 & 0 & 0 & 0 \\
\hline $\boldsymbol{C P}$ & $\mathbf{9}$ & 0 & 1 & 1 & 1 & 0 & 0 & 1 & 1 & 1 & 0 & 0 & 0 & 0 & 0 & 0 \\
\hline $\mathbf{S T}$ & $\mathbf{1 0}$ & 0 & 1 & 0 & 1 & 0 & 0 & 0 & 0 & 0 & 1 & 0 & 0 & 0 & 0 & 1 \\
\hline $\boldsymbol{I N}$ & $\mathbf{1 1}$ & 0 & 1 & 0 & 0 & 1 & 0 & 1 & 1 & 0 & 1 & 1 & 0 & 0 & 0 & 1 \\
\hline SSBS & $\mathbf{1 2}$ & 0 & 1 & 1 & 1 & 1 & 1 & 1 & 1 & 1 & 1 & 1 & 1 & 1 & 1 & 1 \\
\hline $\boldsymbol{P S P}$ & $\mathbf{1 3}$ & 0 & 0 & 1 & 1 & 0 & 0 & 0 & 1 & 1 & 0 & 0 & 0 & 1 & 0 & 0 \\
\hline $\boldsymbol{A F}$ & $\mathbf{1 4}$ & 0 & 1 & 0 & 0 & 0 & 0 & 1 & 0 & 0 & 0 & 0 & 0 & 0 & 1 & 0 \\
\hline $\boldsymbol{D C}$ & $\mathbf{1 5}$ & 0 & 1 & 1 & 1 & 0 & 0 & 1 & 0 & 0 & 0 & 0 & 0 & 1 & 0 & 1 \\
\hline
\end{tabular}




\section{Final Reachability Matrix}

Now that the initial reachability matrix has been built, it is further verified for transitivity. This rule is employed to smooth out the rough edges and maintain concurrency between expert opinions. According to transitivity rule, if ' $i$ leads to $j$ ' and ' $j$ leads to $k$ ' then ' $i$ will also lead to $k$ '. After employing the transitivity rule, the matrix is then modified. The modified matrix now obtained is the final reachability matrix as shown in Table 9.

\section{Table 9: Final reachability matrix}

\begin{tabular}{|c|c|c|c|c|c|c|c|c|c|c|c|c|c|c|c|c|c|}
\hline & & $\mathbf{1}$ & $\mathbf{2}$ & $\mathbf{3}$ & $\mathbf{4}$ & $\mathbf{5}$ & $\mathbf{6}$ & $\mathbf{7}$ & $\mathbf{8}$ & $\mathbf{9}$ & $\mathbf{1 0}$ & $\mathbf{1 1}$ & $\mathbf{1 2}$ & $\mathbf{1 3}$ & $\mathbf{1 4}$ & $\mathbf{1 5}$ & $\mathbf{D P}$ \\
\hline $\boldsymbol{T M C}$ & $\mathbf{1}$ & 1 & 1 & 1 & 1 & 1 & 1 & 1 & 1 & 1 & 1 & 1 & 1 & 1 & 1 & 1 & 15 \\
\hline $\boldsymbol{F T}$ & $\mathbf{2}$ & 0 & 1 & 1 & 1 & 0 & 0 & 0 & 1 & 1 & 0 & 0 & 0 & 1 & 0 & 0 & 6 \\
\hline $\mathbf{S}$ & $\mathbf{3}$ & 0 & 0 & 1 & 0 & 0 & 0 & 0 & 0 & 0 & 0 & 0 & 0 & 0 & 0 & 0 & 1 \\
\hline $\boldsymbol{C}$ & $\mathbf{4}$ & 0 & 0 & 0 & 1 & 0 & 0 & 0 & 0 & 0 & 0 & 0 & 0 & 0 & 0 & 0 & 1 \\
\hline $\boldsymbol{P M}$ & $\mathbf{5}$ & 0 & 0 & 1 & 1 & 1 & 0 & 0 & 1 & 1 & 0 & 0 & 0 & 1 & 0 & 0 & 6 \\
\hline $\boldsymbol{C O}$ & $\mathbf{6}$ & 0 & 1 & 1 & 1 & 1 & 1 & 1 & 1 & 1 & 1 & 1 & 0 & 1 & 0 & 1 & 12 \\
\hline $\boldsymbol{T N}$ & $\mathbf{7}$ & 0 & 1 & 1 & 1 & 1 & 0 & 1 & 1 & 1 & 1 & 0 & 0 & 1 & 0 & 1 & 10 \\
\hline $\boldsymbol{E I}$ & $\mathbf{8}$ & 0 & 1 & 1 & 1 & 0 & 0 & 0 & 1 & 1 & 0 & 0 & 0 & 1 & 0 & 0 & 6 \\
\hline $\boldsymbol{C P}$ & $\mathbf{9}$ & 0 & 1 & 1 & 1 & 1 & 0 & 1 & 1 & 1 & 1 & 0 & 0 & 1 & 0 & 1 & 10 \\
\hline $\mathbf{S T}$ & $\mathbf{1 0}$ & 0 & 1 & 1 & 1 & 1 & 0 & 1 & 1 & 1 & 1 & 0 & 0 & 1 & 0 & 1 & 10 \\
\hline $\boldsymbol{I N}$ & $\mathbf{1 1}$ & 0 & 1 & 1 & 1 & 1 & 0 & 1 & 1 & 1 & 1 & 1 & 0 & 1 & 0 & 1 & 10 \\
\hline $\mathbf{S S B S}$ & $\mathbf{1 2}$ & 0 & 1 & 1 & 1 & 1 & 1 & 1 & 1 & 1 & 1 & 1 & 1 & 1 & 1 & 1 & 14 \\
\hline $\boldsymbol{P S P}$ & $\mathbf{1 3}$ & 0 & 1 & 1 & 1 & 1 & 0 & 1 & 1 & 1 & 1 & 0 & 0 & 1 & 0 & 1 & 10 \\
\hline $\boldsymbol{A F}$ & $\mathbf{1 4}$ & 0 & 1 & 1 & 1 & 1 & 0 & 1 & 1 & 1 & 1 & 0 & 0 & 1 & 1 & 1 & 11 \\
\hline $\boldsymbol{D C}$ & $\mathbf{1 5}$ & 0 & 1 & 1 & 1 & 0 & 0 & 1 & 0 & 0 & 0 & 0 & 0 & 1 & 0 & 1 & 6 \\
\hline & $\mathbf{D e P}$ & 1 & 12 & 14 & 14 & 10 & 3 & 10 & 12 & 12 & 9 & 4 & 2 & 13 & 3 & 10 & \\
\hline
\end{tabular}

\section{Level Partitions}

The next step is to assign levels to each of our identified antecedents. Once the reachability matrix is obtained, the reachability set and antecedent set for each of our antecedents is to be found out. The antecedent set has itself and the variables which it may help achieve while the antecedent set has the variables which may help it including itself. After identifying the variables in these sets, the intersection set of these sets is found for all the variables. The variables for which the intersection set and the reachability set are same; the 
highest level of the ISM hierarchy is given to them. Now that the variables of the highest level are identified, they are separated from the other variables and iteration is repeated to identify the variables in the next level. This iterative process is continues until levels of each variable are found. In this iterative process, nine levels have been identified. The highest level in the hierarchy has been occupied by the success factors Linking Six Sigma to Suppliers and Linking Six Sigma. On the other hand, the final level is occupied by upper management commitment as shown in Table 10.

Table 10: Level matrix

\begin{tabular}{|c|c|}
\hline Variables & Level \\
\hline S,C & Level1 \\
\hline EI,PSP & Level2 \\
\hline FT,PM & Level3 \\
\hline TN,DC & Level4 \\
\hline CP,ST & Level5 \\
\hline IN,AF & Level6 \\
\hline CO & Level7 \\
\hline SSBS & Level8 \\
\hline TMC & Level9 \\
\hline
\end{tabular}

\section{References:}

Aboelmaged, M.G. (2010).Reconstructing Six Sigma barriers in manufacturing and service organisations - The effects of organisational parameters. International Journal of Quality \& Reliability Management, 28(5), 519-541.

Ali, D., and Govindan, K. (2011). An analysis of the drivers affecting the implementation of green supply chain management. Resources, Conservation and Recycling, 55(6):659-667.

Anand, G., Ward, P. T., \& Tatikonda, M. V. (2010). Role of explicit and tacit knowledge in Six Sigma projects: An empirical examination of differential project success. Journal of Operations Management, 28(4):303-315.

Anderson, J. C., \& Gerbing, D. W. (1988).Structural equation modelling in practice: a review and recommended two-step approach. Psychological Bulletin, 103(2), 411-423. 
Anderson, M. G.,\& Gerbing, D. W. (1982). Some methods for re-specifying measurement models to obtain unidimensional construct measurement. Journal of Marketing Research, 19:453- 460.

Antony, J., \& Banuelas, R. (2002). Key ingredients for the effective implementation of Six Sigma program. Measuring Business Excellence, 6(4), 20-27.

Antony, J., Kumar, M., \& Madu, C. N. (2005). Six Sigma in small-and mediumsized UK manufacturing enterprises: Some empirical observations. International Journal of Quality \& Reliability Management, 22(8), 860-874.

Antony, J., Antony, J. F., Kumar, M. and Cho, R.B. (2006).Six Sigma in service organisations Benefits, challenges and difficulties, common myths, empirical observations and success factors. International Journal of Quality \& Reliability Management, 24 (3): 294-311.

Antony, J. and Desai, D. (2009). Assessing the status of Six Sigma implementation in the Indian Industry. Management Research News, 32(5):413-423.

Antony, J., Gijo, E. V., \& Childe, S. J. (2012). Case study in Six Sigma methodology: manufacturing quality improvement and guidance for managers. Production Planning \& Control, 23(8), 624-640.

Arumugam, V., Antony, J., \& Kumar, M. (2013). Linking learning and knowledge creation to project success in Six Sigma projects: An empirical investigation. International Journal of Production Economics, 141(1):388-402.

Miguel, P. A. C., and Andrietta, J. M. (2009). Benchmarking Six Sigma application in Brazil: Best practices in the use of the methodology. Benchmarking: An International Journal, 16(1):124-134.

Aldag, R. J., \& Steams, T. M. (1988). Issues in research methodology. Journal of Management, 14(2), 253-276.

Arumugam, V., Antony, J. and Kumar, M. (2013). Linking learning and knowledge creation to project success in Six Sigma projects: An empirical investigation", International Journal of Production Economics, 141(1):388-402.

Bagozzi, R. P. \& Phillips, L. W. (1982). Representing and testing organizational theories: a holistic construal. Administrative Science Quarterly, 27:459-489.

Banuelas, R. \& Antony, J. (2002). Critical success factors for the successful implementation of Six Sigma projects in organizations. The TQM Magazine, 14(2):92-99.

Banuelas, R. \& Antony, J. (2002). Key ingredients for the effective implementation of Six Sigma program. Measuring business excellence, 6(4):20-27. 
Banuelas, R., \& Antony, J. (2004). Six Sigma or design for Six Sigma? The TQM Magazine, 16(4), 250-263.

Barney, J.B. (1991). Firm resources and sustained competitive advantage. Journal of Management, 17(1):99-120.

Bertrand, J. W. M, \& Fransoo, J. C. (2002). Operations management research methodologies using quantitative modeling. International Journal of Operations \& Production Management, 22(2):241-264.

Breyfogle, F.W. III, Cupello, J.M. \& Meadows, B. (2001). Managing Six Sigma: A Practical Guide to Understanding, Assessing and Implementing the Strategy that Yields Bottom-Line Success. Wiley, New York, NY.

Braunscheidel, M. J., Hamister, J.W., Suresh, N.C. \& Star, H. (2011). An institutional theory perspective on Six Sigma adoption. International Journal of Operations \& Production Management, 31(4):423 - 451.

Braunscheidel, M. J. \& Suresh. N. C. (2009). The Organizational Antecedents of a Firm's Supply Chain Agility for Risk Management and Response. Journal of Operations Management, 27 (2): 119-140.

Brun, A. (2011). Critical success factors of Six Sigma implementations in Italian companies. International Journal of Production Economics, 131(1):158164.

Buch, K., \& Tolentino, A. (2006). Employee perceptions of the rewards associated with Six Sigma. Journal of Organizational Change Management, 19(3), 356-364.

Burch V, R. F., Strawderman, L., \& Bullington, S. (2014). Global corporation rollout of ruggedised handheld devices: a Lean Six Sigma case study. Total Quality Management \& Business Excellence, (ahead-of-print), 1-15. DOI:10.1080/14783363.2014.934521

Chakrabarty, A., \& Kay Chuan, T. (2009). An exploratory qualitative and quantitative analysis of Six Sigma in service organizations in Singapore. Management Research News, 32(7), 614-632.

Chakravorty, S.S. (2009). Six Sigma programs: An implementation model. International Journal of Production Economics, 119(1):1-16.

Chen, I. J., \& Paulraj, A. (2004). Towards a theory of supply chain management: the constructs and measurements. Journal of operations management, 22(2):119-150.

Choi, B., Kim, J., Leem, B-H., and Lee, C-Y \& Hong, H-K. (2012). Empirical analysis of the relationship between Six Sigma management activities and corporate competitiveness: Focusing on Samsung Group in Korea, International Journal of Operations \& Production Management, 32(5):528-550. 
Choo, A. S., Linderman, K. W., \& Schroeder, R. G. (2007a). Method and context perspectives on learning and knowledge creation in quality management. Journal of Operations Management, 25(4): 918-931.

Choo, A. S., Linderman, K. W., Schroeder, R. G. (2007b). Method and psychological effects on learning behaviors and knowledge creation in quality improvement projects. Management Science, 53(3): 437-450.

Churchill, G.A. (1979). A paradigm for developing better measures of marketing constructs. Journal of Marketing Research, 16 (2):64-73.

Cohen, J., P. Cohen, S.G. West. and L.S. Aiken. (2003). Applied Multiple Regression/Correlation Analysis for the Behavioural Sciences. $3^{\text {rd }}$ edn, Hillsdale, NJ: Erlbaum.

Cooper, D. R. \& Schindler, P. S. (2001). Business research methods. New York: McGraw-Hill Companies.

Cronemyr, P., Eriksson, M., \& Jakolini, S. (2014). Six Sigma diplomacy-the impact of Six Sigma on national patterns of corporate culture. Total Quality Management \& Business Excellence, 25(7-8), 827-841.

Coronado, R.B. and Antony, J. (2002), "Critical success factors for the successful implementation of Six Sigma projects in organizations", The TQM Magazine, 14(2):92-9.

Cronbach, L. J. (1951). Coefficient alpha and the internal structure of tests. Psychometrika, 16(3), 297-334.

Crozier, M. and Thoenig, J.C. (1976). The regulation of complex organized systems. Administrative Science Quarterly, 2 (4):547-70.

Desai, D.A. (2008), "Improving productivity and profitability through Six Sigma: experience of a small-scale jobbing industry", International Journal of Productivity and Quality Management, 3(3): 290-310.

Desai, D. A., Antony, J. and Patel, M. B. (2011), "An assessment of the critical success factors for Six Sigma implementation in Indian industries". International Journal of Productivity and Performance Management, 61(4), 426-444.

Desai, D. A. and Patel, M. B. (2009). Impact of Six Sigma in a developing economy: analysis on benefits drawn by Indian industries. Journal of Industrial Engineering and Management, 2 (3):517-38.

Desai, D. A. and Patel, M. B. (2010).Six Sigma implementation barriers in Indian industries - survey results and case studies. International Journal of Business Excellence, 3(2):142-62.

de Mast, J., and Lokkerbol, J. (2012). An analysis of the Six Sigma DMAIC method from the perspective of problem solving. International Journal of Production Economics, 139(2):604-614. 
de Treville, S., Edelson, N. M., Kharkar, A. N., Avanzi, B. (2008). Constructing useful theory: The case of Six Sigma. Operations Management Research, 1(1): 15-23.

Dillman, D. (2000). "Elements of the tailored design method". New York: Wiley.

Dillman, D.A. (1978), "Mail and Telephone Surveys: The Total Design Method", Wiley, New York.

Easton, G.S. and Rosenzweig, E.D. (2012). The role of experience in Six Sigma project success: An empirical analysis of implementation projects. Journal of Operations Management, 30(7/8):481-493.

Eckes, G. (2001). The Six Sigma Revolution: How General Electric and Others Turned Process Into Profits. Wiley, New York, NY.

Eisenhardt, K. M. (1989). Building theories from case study research. Academy of management review, 14(4):532-550.

Firka, D. (2010). Six Sigma: an evolutionary analysis through case studies. The TQM Journal, 22(4), 423-434.

Flynn, B. B., Sakakibara, S., Schroeder, R. G., Bates, K. A., \& Flynn, E. J. (1990). Empirical research methods in operations management. Journal of operations management, 9(2): 250-284.

Gijo, E. V., \& Scaria, J. (2014). Process improvement through Six Sigma with Beta correction: a case study of manufacturing company. The International Journal of Advanced Manufacturing Technology, 71(1-4), 717-730.

Gosnik, D. and Vujica-Herzog, N. (2010). Success factors for Six Sigma implementation in Slovenian manufacturing companies. Advances in Production Engineering \& Management, 5(4):205-216.

Handfield, R. B., \& Melnyk, S. A. (1998). The scientific theory-building process: a primer using the case of TQM. Journal of operations management, 16(4), 321-339.

Hair, J.F., Anderson, R.E., Tatham, R.L., Black, W.C. (1995), "Multivariate Data Analysis, With Readings", 4th Edition. Prentice Hall, Englewood Cliffs, New Jersey.

Hansen, G. S. \& Wernerfelt, B. (1989). Determinants of firm performance: the relative importance of organizational and economic factors. Strategic Management Journal, 14:607-618.

Harman, B. H., (1976), "Modern factor analysis", $3^{\text {rd }}$ edition (rev.), Chicago: University of Chicago Press.

Harry, M.J. (1998), "Six Sigma: a breakthrough strategy for profitability", Quality Progress, May: 60-64. 
Heckl, D., Moormann, J. and Rosemann, M. (2010). Uptake and success factors of Six Sigma in the financial services industry. Business Process Management Journal, 16(3):436-472.

Jeyaraman, K. and Teo, L.K. (2010). A conceptual framework for critical success factors of lean Six Sigma: Implementation on the performance of electronic manufacturing service industry. International Journal of Lean Six Sigma, 1 (3): $191-215$.

Jin, T., Janamanchi, B. and Feng, Q. (2011). Reliability deployment in distributed manufacturing chains via closed-loop Six Sigma methodology. International Journal of Production Economics, 130(1):97-103.

Jones, E.C., Parast, M.M. \& Adams, S.G.(2010). A framework for effective Six Sigma implementation. Total Quality Management \& Business Excellence, 21(4):415-424.

Kaushik, P., \& Khanduja, D. (2009). Application of Six Sigma DMAIC methodology in thermal power plants: A case study. Total Quality Management \& Business Excellence, 20(2), 197-207.

Ketokivi, M., \& Choi, T. (2014). Renaissance of case research as a scientific method. Journal of Operations Management, 32(5):232-240.

Kim, D-S. (2010), "Eliciting success factors of applying Six Sigma in an academic library", Performance Measurement \& Metrics, 11(1):25-38.

Krueger, D. C., Mellat-Parast, M., \& Adams, S. (2014). Six Sigma implementation: a qualitative case study using grounded theory. Production Planning \& Control, 25(10), 873-889.

Kumar, U. D., Nowicki, D., Ramirez-Marquez, J. E., and Verma, D. (2008). "On the optimal selection of process alternatives in a Six Sigma Implementation", International Journal of Production Economics, 111(2):456-467.

Kumar,M., Antony, J. and Tiwari, M.K. (2011). Six Sigma implementation framework for SMEs- a roadmap to manage and sustain the change. International Journal of Production Research, 49(18):5449-5467.

Kwak, Y. H., \& Anbari, F. T. (2006). Benefits, obstacles, and future of Six Sigma approach. Technovation, 26(5), 708-715.

Lee, K. C., \& Choi, B. (2006). Six Sigma management activities and their influence on corporate competitiveness. Total Quality Management \& Business Excellence, 17(7), 893-911.

Linderman, K., Schroeder, R.G., Zaheer, S. and Choo, A.S. (2003). Six Sigma: a goal-theoretic perspective. Journal of Operations Management, 21:193-203.

Linderman, K., Schroeder, R. G., Choo, A. S. 2006. Six Sigma: The role of goals in improvement teams. Journal of Operations Management, 24(6): 779-790. 
Lucato, W. C., Vieira Júnior, M., \& Santos, J. C. D. S. (2014). Eco-Six Sigma: integration of environmental variables into the Six Sigma technique. Production Planning \& Control, (ahead-of-print), 1-12. DOI:10.1080/09537287.2014.949896

Malhotra, M.K. \& Grover, V. (1998). An assessment of survey research in POM: from constructs to theory. Journal of Operations Management, 16(4):407-425.

Mandal, A. \& Deskmukh. S. G. (1994). Vendor selection using interpretive structural modeling (ism). International Journal of Operations and Production Management, 14 (6):52-59.

Mardia, K.V. 1970. Measures of Multivariate Skewness and Kurtosis with Applications. Biometrika 57 (3): 519-530.

Markman, G., \& Krause, D. (2014). Special Topic Forum on Theory Building Surrounding Sustainable Supply Chain Management. Journal of Supply Chain Management, 50(3), i-ii.

McAdam, R., \& Lafferty, B. (2004). A multilevel case study critique of Six Sigma: statistical control or strategic change? International Journal of Operations \& Production Management, 24(5), 530-549.

Meredith, J. R., Raturi, A., Amoako-Gyampah, K., \& Kaplan, B. (1989). Alternative research paradigms in operations. Journal of operations management, 8(4), 297-326.

Meredith, J. (1998). Building operations management theory through case and field research. Journal of operations management, 16(4):441-454.

Monteiro de Carvalho, M., Lee Ho, L., \& Helena Boarin Pinto, S. (2014). The Six Sigma program: an empirical study of Brazilian companies. Journal of Manufacturing Technology Management, 25(5), 602-630.

Nair, A., Malhotra, M. K., \& Ahire, S. L. (2011). Toward a theory of managing context in Six Sigma process-improvement projects: An action research investigation. Journal of Operations Management, 29(5), 529-548.

Nonthaleerak, P. \& Hendry, L. (2008). Exploring the Six Sigma phenomenon using multiple case study evidence. International Journal of Operations and Production Management, 28:279-303.

Nunnally, J.C. (1978), "Psychometric Theory", McGraw-Hill, New York.

Pal Pandi, A., Rajendra Sethupathi, P. V., \& Jeyathilagar, D. (2014). The IEQMS model for augmenting quality in engineering institutions-an interpretive structural modelling approach. Total Quality Management \& Business Excellence, (ahead-of-print), 1-17.

Pedhazur, E., and Schmelkin, L. (1991). "Measurement, design and analysis: an integrated approach", Hillsdale, NJ: Erlbaum. 
Pepper, M. P. J., \& Spedding, T. A. (2010). The evolution of lean Six Sigma. International Journal of Quality \& Reliability Management, 27(2), 138-155.

Prashar, A. (2014). Process improvement in farm equipment sector (FES): a case on Six Sigma adoption. International Journal of Lean Six Sigma, 5(1):62 -88 .

Prashar, A. (2015). Six Sigma adoption in public utilities: a case study. Total Quality Management \& Business Excellence, (ahead-of-print), 1-28.

Rockart, J. F. (1979). Critical success factors. Harvard Business Review, 57(2), 81-91.

Saghaei, A(2012)."Enhanced Rolled Throughput Yield: A new Six Sigma-based performance measure", International Journal of Production Economics, $140(1): 368-373$.

Schroeder, R. G., Linderman, K., Liedtke, C., Choo, A. S. (2008). Six Sigma: Definition and underlying theory. Journal of Operations Management, 26(4): 536-554.

Schoenherr, T. \& Mabert, V. A. (2008). The use of bundling in B2B online reverse auctions. Journal of Operations Management, 26(1):81-95.

Seth, D. \& Rastogi, S. C. (2004). Global Management Solutions - Demystified. Thomson Asia, Singapore.

Shafer, S. M. \& Moeller, S. B.(2012). The effects of Six Sigma on Corporate performance: An empirical investigation. Journal of Operations Management, 30(7/8):521-532.

Snee, R.D. (2004). Six Sigma: the evolution of 100 years of business improvement methodology. International Journal of Six Sigma and Competitive Advantage, 1(1):4-20.

Soti, A., Shankar, R., \& Kaushal, O. P. (2010). Modeling the enablers of Six Sigma using interpreting structural modeling. Journal of Modelling in Management, 5(2), 124-141.

Stevens, J.P. (2002). Applied multivariate statistics for the social sciences. 4th edition, Hillsdale, NJ: Erlbaum.

Strauss, A., \& Corbin, J. M. (1990). Basics of qualitative research: Grounded theory procedures and techniques. Sage Publications, Inc.

Sushil (2012).Interpreting the Interpretive Structural Model. Global Journal of Flexible Systems Management, 13(2):87-106.

Swamidass, P. M. (1991). Empirical science: new frontier in operations management research. Academy of management review, 16(4), 793-814. 
Swink, M. \& Jacobs, B. W. (2012). Six Sigma adoption: operating performance impacts and contextual drivers of success. Journal of Operations Management, 30(6):437-453.

Tabachnick, B. G., \& Fidell, L. S. (2007), Using multivariate statistics, 5th edition, Boston: Allyn\& Bacon.

Tang, L.C., Goh, T. N., Lam, S. W. \& Zhang, C. W. (2007), "Fortification of Six Sigma: expanding the DMAIC toolset", Quality and Reliability Engineering International, 23: 3-18.

Tanik, M., \& Sen, A. (2012). A six sigma case study in a large-scale automotive supplier company in Turkey. Total Quality Management \& Business Excellence, 23(3-4), 343-358.

Tiwari, M. K., Antony, J. \& Montgomery, D. C. (2008). Editorial note for the special issue on effective decision support to implement lean and Six Sigma methodologies in the manufacturing and service sectors. International Journal of Production Research, 46(23):6563-6566.

Tomkins, R. (1997). GE beats expected 13\% rise, Financial Times, 10 Oct, p.22.

Tranfield, D., Denyer, D. \& Smart, P. 2003. Towards a methodology for developing evidence-informed management knowledge by means of a systematic review. British Journal of Management, 14(3),207-222.

Vinodh, S., Kumar, S. V., \& Vimal, K. E. K. (2014). Implementing lean sigma in an Indian rotary switches manufacturing organisation. Production Planning \& Control, 25(4), 288-302.

Voelkel, J.G. (2002).Something's missing - an education in statistical methods will make employees more valuable to Six Sigma corporations. Quality Progress, May:98-101.

Voss, C., Tsikriktsis, N., \& Frohlich, M. (2002). Case research in operations management. International journal of operations \& production management, 22(2): 195-219.

Wacker, J. G. (1998). A definition of theory: research guidelines for different theory-building research methods in operations management. Journal of operations management, 16(4):361-385.

Wacker, J. G. (2004). A theory of formal conceptual definitions: developing theory-building measurement instruments. Journal of Operations Management, 22(6), 629-650.

Warfield, J. W. (1974), "Developing Interconnected Matrices in Structural Modelling”. IEEE Transcript on Systems, Men and Cybernetics, 4(1):51-81.

Whetten, D. A. (1989). What constitutes a theoretical contribution? Academy of Management Review, 14(4):490-495. 
Zhang, M., Wang, W., Goh, T. N., \& He, Z. (2014). Comprehensive Six Sigma application: a case study. Production Planning \& Control, (ahead-of-print), 116. DOI:10.1080/09537287.2014.891058

Zu, X., Fredendall, L. D., \& Douglas, T. J. (2008). The evolving theory of quality management: the role of Six Sigma. Journal of operations Management, 26(5):630-650.

Zu, X., Robbins, T.L. \& Frendendall, L.D. (2010). Mapping the critical links between organizational culture and TQM/Six Sigma practices. International Journal of Production Economics, 123(1):86-106. 